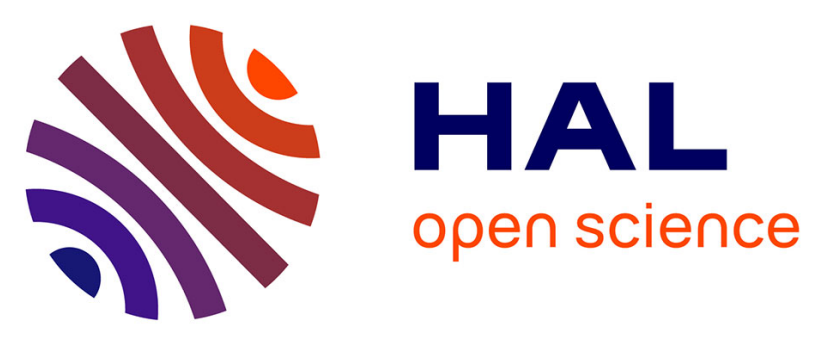

\title{
A Lower Cretaceous Lagerstätte from France: a taphonomic overview of the Angeac-Charente vertebrate assemblage
}

Lee Rozada, Ronan Allain, Romain Vullo, Jean Goedert, Dominique Augier, Amandine Jean, Jonathan Marchal, Claire Peyre de Fabrègues, Martin Qvarnström, Rafael Royo-torres

\section{To cite this version:}

Lee Rozada, Ronan Allain, Romain Vullo, Jean Goedert, Dominique Augier, et al.. A Lower Cretaceous Lagerstätte from France: a taphonomic overview of the Angeac-Charente vertebrate assemblage. Lethaia, 2021, 54 (2), pp.141-165. 10.1111/let.12394 . insu-03120199

\section{HAL Id: insu-03120199 \\ https://hal-insu.archives-ouvertes.fr/insu-03120199}

Submitted on 25 Jan 2021

HAL is a multi-disciplinary open access archive for the deposit and dissemination of scientific research documents, whether they are published or not. The documents may come from teaching and research institutions in France or abroad, or from public or private research centers.
L'archive ouverte pluridisciplinaire HAL, est destinée au dépôt et à la diffusion de documents scientifiques de niveau recherche, publiés ou non, émanant des établissements d'enseignement et de recherche français ou étrangers, des laboratoires publics ou privés. 


\title{
A Lower Cretaceous Lagerstätte from France: a taphonomic overview of the Angeac-Charente vertebrate assemblage
}

\author{
LEE ROZADA (D), RONAN ALLAIN, ROMAIN VULLO, JEAN GOEDERT, DOMINIQUE AUGIER, AMAN- \\ DINE JEAN, JONATHAN MARCHAL, CLAIRE PEYRE DE FABRĖGUES (D, MARTIN QVARNSTRÖM(D) AND \\ RAFAEL ROYO-TORRES (1)
}

LETHAIA

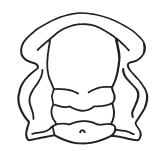

Rozada, L., Allain, R., Vullo, R., Goedert, J., Augier, D., Jean, A., Marchal, J., Peyre de Fabrègues, C., Qvarnström, M., \& Royo-Torres, R. 2020: A Lower Cretaceous Lagerstätte from France: a taphonomic overview of the Angeac-Charente vertebrate assemblage. Lethaia, https://doi.org/10.1111/let.12394.

Terrestrial ecosystems from the Lower Cretaceous of Europe and bonebeds formed in swampy environments are poorly known. The Berriasian-early Valanginian AngeacCharente site in France represents an example of both. Nine field campaigns have yielded thousands of fossils of over a hundred taxa, including 16 taxa from vertebrate macroremains with numerous trample and crocodile bite marks; 22 taxa from the abundant vertebrate microremains; $>10$ vertebrate coprolite morphotypes with plant and vertebrate inclusions; abundant sauropod and stegosaur tracks including some preserved in '4-D'; termite coprolites; mollusc moulds; ostracods and plants, including coniferous wood, cones, leaves and cuticle fragments, charophytes and pollen. The richness, diversity and preservation of the fossils qualify the site as a fossil-Lagerstätte. The site represents a 'snapshot' into a Lower Cretaceous ecosystem. This is supported by REE analyses of biogenic apatite and sediment samples, the fossils being found in a single stratigraphical interval and the record of sedimentological and taphonomic 'frozen scenes'. The Angeac-Charente bonebed is highly diverse, dominated by an ornithomimosaur taxon, and contains both macro- and microfossils. This indicates a complex formation, likely primarily influenced by ecological and biologic processes, but also significant physical processes. These include crocodyliform predation and/or scavenging on turtles, ornithomimosaurs and fishes; probable mass mortality occurrence of an ornithomimosaur herd; possible social behaviour of stegosaurs; limited hydraulic transport of most sauropod bones and intense dinoturbation. $\square$ Bonebed, Early Cretaceous, ecosystem, Lagerstätte, swamp, taphonomy.

\begin{abstract}
Lee Rozada [lrozada@mnhn.fr], and Ronan Allain [rallain@mnhn.fr], Centre de Recherche en Paléontologie - Paris, UMR 7207 (MNHN- Sorbonne Université -CNRS), Muséum National d'Histoire Naturelle, CP 38, 57 rue Cuvier Paris Cedex 05 F-75231, France; Romain Vullo [romain.vullo@univ-rennes1.fr], Univ Rennes, CNRS, Géosciences Rennes, UMR 6118, Rennes 35000, France; Jean Goedert [jean.goedert@protonmail.fr], De la préhistoire à l'actuel: culture, environnement et anthropologie, UMR 5199, Université de Bordeaux, Bâtiment B8 Pessac Cedex 33615, France; Dominique Augier [laurencelavie@orange.fr], Musée d'Angoulême, 1 rue Friedland Angoulême 16000, France; Amandine Jean [amandine-jean@wanadoo.fr], Jonathan Marchal [jonathan.marchal@outlook.com], Independent Researcher, France; Claire Peyre de Fabrègues [claire.pdf@gmail.com], Centre for Vertebrate Evolutionary Biology, Institute of Palaeontology, Yunnan University, Kunming 650091, China; Martin Qvarnström [martin.qvarnstrom@ebc.uu.se], Department of Organismal Biology, Evolutionary Biology Centre, Uppsala University, Norbyvägen 18A Uppsala 752 36, Sweden; Rafael RoyoTorres[royo@dinopolis.com], Department of Specific Didactics, Facultad de Ciencias Sociales y Humanas, University of Zaragoza, Ciudad escolar $s / n$, Teruel, 44003, Spain; manuscript received on 20/03/2019; manuscript accepted on 18/05/2020.
\end{abstract}

The opportunity to study extinct vertebrate behaviour and ecology is rare (e.g. Hasiotis et al. 2007). However, behaviour and palaeoecology can be inferred from remarkable vertebrate concentrations, such as bonebeds (i.e. Rogers \& Kidwell 2007) and trace fossils (i.e. Hasiotis et al. 2007). In terrestrial ecosystems, evidence of interspecific interactions (such as predation, parasitism and overall trophic structures of ecological communities) can be inferred from fossilized gut and faecal contents (Hunt et al. 1994; Richter \& Baszio 2001;
Chin 2007; Qvarnström et al. 2019a, 2019b), bite marks on bones (Fiorillo 1991; Chure et al. 1998; Rogers et al. 2003; Jennings \& Hasiotis 2006; Reisz \& Tsuji 2006; Niedźwiedzki et al. 2011; Gônet et al. 2018), taphonomic studies of fossil assemblages, such as those found in multitaxic bonebeds (Brinkman et al. 2007), and isotope geochemistry (e.g. Hassler et al. 2018). Conspecific relationships, such as sociality, can be deduced from trackways (Lockley 1986, 1998; Hasiotis et al. 2007) and mass mortality occurrences, such 
as those found in monotaxic or monodominant bonebeds (e.g. Ryan et al. 2001; Brinkman et al. 2007; Varricchio et al. 2008; Cullen et al. 2013).

Fossil fauna and flora from Lower Cretaceous terrestrial deposits of Europe are known from numerous localities in the Purbeck and Wealden groups (Burton 1998; Batten 2002). However, they come from distinct depositional environments and their precise stratigraphical positions are not well constrained. Consequently, any reconstitutions of interactions between organisms should be used with caution. Until recently, the Konservat-Lagerstätte at the base of La Huérgina Formation (HauterivianBarremian), in the Las Hoyas Basin, in the centre east of Spain, was the only multitaxic site that provided detailed insights into a vertebrate ecosystem of the Lower Cretaceous of Europe (Sanz et al. 1988; Buscalioni \& Fregenal-Martínez 2010).

The Angeac-Charente bonebed contains a rich record of an Early Cretaceous, terrestrial ecosystem from a swampy environment (Néraudeau et al. 2012). Fieldwork conducted at the site between 2010 and 2017 yielded $\geq 7500$ identified (taxonomically and anatomically) vertebrate macroremains (that are fossil pieces $\geq 5 \mathrm{~mm}$ in maximal length), nearly 64,000 unidentified bone fragments, thousands of vertebrate microremains $(<5 \mathrm{~mm}$ in maximal length) collected by screening, 3320 vertebrate coprolites containing many plant and vertebrate inclusions, $\geq 130$ dinosaur track casts, $\geq 140$ mollusc moulds and numerous plant remains, including palynomorphs and charophyte algae (Allain et al. 2011, 2014; R. Allain, R. Vullo, L. Rozada, J. Anquetin, R. Bourgeais, J. Goedert, M. Lasseron, J. E. Martin, A. Pérez-Garcia, C. Peyre de Fabrègues, R. Royo-Torres, D. Augier, G. Bailly, L. Cazes, Y. Desprès, B. Gomez, F. Goussard, T. Lenglet, R. Vacant, Mazan \& J.F. Tournepiche, unpublished data; Benoît et al. 2017; Néraudeau et al. 2012; Polette et al. 2018).

The bonebed was firstly dated to the HauterivianBarremian based on its palynomorph, ostracod and charophyte assemblages (Néraudeau et al. 2012). However, more detailed studies of the charophytes (Benoît et al. 2017) and palynomorphs (Polette et al. 2018) suggest a Berriasian to early Valanginian age for the Angeac-Charente locality, which agrees with its faunal content (R. Allain, R. Vullo, L. Rozada, J. Anquetin, R. Bourgeais, J. Goedert, M. Lasseron, J. E. Martin, A. Pérez-Garcia, C. Peyre de Fabrègues, R. Royo-Torres, D. Augier, G. Bailly, L. Cazes, Y. Desprès, B. Gomez, F. Goussard, T. Lenglet, R. Vacant, Mazan \& J.F. Tournepiche, unpublished data). Coupled with sedimentological data, the richness, diversity and quality of preservation of these fossils give a unique opportunity to study and reconstruct an Early Cretaceous terrestrial ecosystem from Europe. Here, we present an overview of the taphonomy of the Angeac-Charente bonebed and the first conclusions and hypotheses about the palaeoenvironment and palaeoecology of the site.

\section{Material and methods}

\section{Institutional abbreviations}

ANG, Angeac-Charente Collection, Musée d'Angoulême. All the palaeontological and sedimentological material collected in Angeac-Charente is housed in the collections of the Musée d'Angoulême or temporarily deposited at the Muséum National d'Histoire Naturelle of Paris.

\section{Fieldwork}

The Angeac-Charente site is located in southwestern France, in the Charente department, $700 \mathrm{~m}$ north of the village of Angeac-Charente, between Cognac and Angoulême (Fig. 1; Allain et al. 2011, 2014; Néraudeau et al. 2012; Polette et al. 2018).

Between 2010 and 2018, excavations were conducted every summer, for a total of nine consecutive years, each lasting circa four weeks and involving about 40 people. A total surface of approximately $724 \mathrm{~m}^{2}$ has been manually and mechanically excavated (i.e. using manual tools vs excavator, respectively). From 2010 to 2018, excavations extended from the first mechanical excavation on the CG plot (CG1 to CG9). The palaeontological excavations are divided into two main plots, plot CG in the northwest and plot $R$ in the southeast (and in the

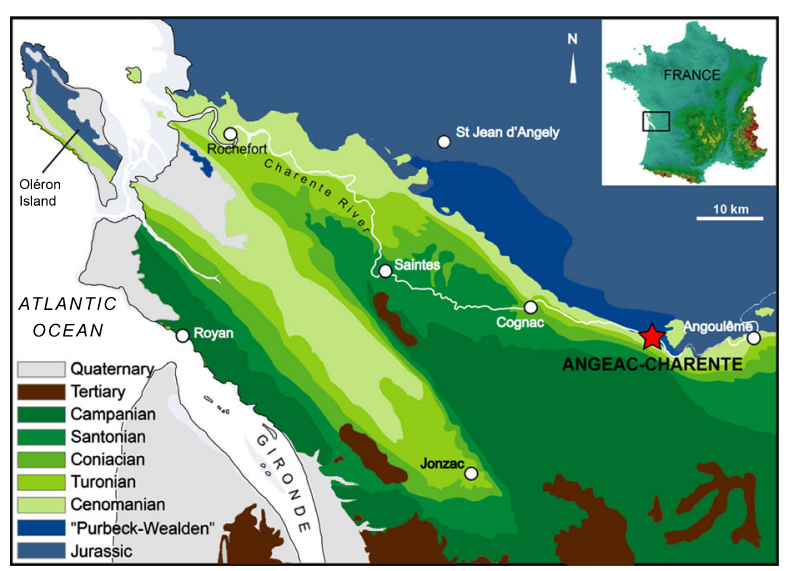

Fig. 1. Angeac-Charente locality and geological map. Modified from Néraudeau et al. (2012). 
southwest of the commercial quarry; Fig. 2). Plot R (R1-3) has been excavated since 2013. Spatial information (boundaries of manually and mechanically excavated plots, sedimentological sections and structures, fossils of interest) have been recorded by manual mapping in 2010, using a theodolite from 2011 to 2014, and a total station (Geomax Zipp10 Pro Series) from 2015 to 2018 . These spatial data have been virtually projected and analysed using ArcGIS Desktop ver. 10.3.1 and 3-D Analyst extension (Esri 19992015). The horizontal projection system used is NTF Lambert Zone III, based on the geographic coordinate system GCS_NTF (used on the southern French metropolitan territory, south of $\mathrm{N} 45.45^{\circ}$ ). The vertical coordinate system is NGF_IGN69 (altitude above mean sea level of France; Esri 2012). Unfortunately, a technical problem arose during 2011 and 2012 field campaigns making these spatial data unusable. Sedimentological drilling and lithological sections have been carried out (Figs 2, 3, 4), and several tons of sediment have been sieved and sorted for microremains. The description of these is not the scope of this study (instead see R. Allain, R. Vullo, L. Rozada, J. Anquetin, R. Bourgeais, J. Goedert, M. Lasseron, J. E. Martin, A. Pérez-Garcia, C. Peyre de Fabrègues, R. Royo-Torres, D. Augier, G. Bailly, L. Cazes, Y. Desprès, B. Gomez, F. Goussard, T. Lenglet, R. Vacant, Mazan \& J.F. Tournepiche, unpublished data).

\section{Geochemical data}

Previous clay diffraction analysis has demonstrated the monotony and homogeneity of the sedimentological assemblage, indicating that the different facies accumulated under the same conditions of diagenesis, climate and probably water quality, with the detrital minerals derived from the same source (Néraudeau et al. 2012). To further complete these results, we have analysed Rare Earth Element (REE) and Yttrium (REY, when including Yttrium) concentrations of biogenic apatites (bones) and sediments. Depending on their origin, fluids are characterized by different REY patterns. For instance, rivers have generally a flat 'continental-type' pattern compared to typical 'seawater-type' patterns which are relatively enriched for the heavy-REE (HREE) and present typical anomalies such as a negative Cerium anomaly and a positive Yttrium anomaly (Lawrence et al. 2006; Fig. 5C). The fluids within the sediments, termed pore-water sediments, from different burial environments also exhibit different REY patterns. During early diagenesis, REY from pore-water sediments are incorporated in biogenic apatite (Trotter et al. 2016 and reference therein). If subsequent diagenetic stages do not modify the early diagenetic REY record, then REY analyses provide valuable chemical composition information concerning the burial environment and can be used to untangle different potential taphonomic histories within the same assemblage (Trueman \& Benton 1997; Trueman 1999).

These analyses were performed on five sediment samples, covering the whole stratigraphical section, sampled during the 2015 field campaign (CG3 plot, Fig. 2A: SSCG3; Fig. 5A, D), as well as 4 apatite samples and their enclosing sediments, all collected in Unit 3 clay, sampled during the 2016 field campaign (Figs 2A, 5B). The latter include the following: two ornithomimosaur caudal vertebrae, from R1 (Fig. 2 A: RO3) and CG3 (Fig. 2A: CGO1), to test lateral differences; and two sauropod bones from R1, one well-preserved diapophysis (Fig. 2A: RS3 and one bone pebble (Fig. 2A: RSG8) to test transportation differences. The five sediments along with the four apatite samples (Table S1), weighing around $50 \mathrm{mg}$, were dissolved overnight in screw-top Teflon bombs (Savillex) using $2 \mathrm{M}$ hydrofluoric acid (HF) and $2 \mathrm{ml}$ of $14 \mathrm{M}$ nitric acid $\left(\mathrm{HNO}_{3}\right)$ at $150^{\circ} \mathrm{C}$. The solutions were rinsed and diluted to $25 \mathrm{ml}$ with distilled water. Each sample solution was then diluted 100 times in $0.5 \mathrm{M} \mathrm{HNO}_{3}$ containing $2 \mathrm{ppb}$ Indium as internal standard. REY elements (La, Ce, Pr, Nd, Sm, Eu, Gd, $\mathrm{Tb}, \mathrm{Dy}, \mathrm{Ho}, \mathrm{Er}, \mathrm{Tm}, \mathrm{Yb}, \mathrm{Lu}$ and $\mathrm{Y}$ ) were then analysed using an Agilent 7500 Inductively Coupled Plasma-Mass Spectrometer (ICP-MS; UMR CNRS 5276, ENS de Lyon).

\section{Fossil counting}

We distinguished several kinds of fossils based on their size: the macroremains recovered during manual excavation $(\geq 5 \mathrm{~mm})$, and microremains recovered after sampling and screening-washing of the sediments $(<5 \mathrm{~mm})$. Among macroremains, according to the nomenclature of Eberth et al. (2007), we distinguish the macrofossils which are $\geq 5 \mathrm{~cm}$ long, and the microfossils which are $<5 \mathrm{~cm}$ long but visible to naked eye during the excavation (i.e. $>5 \mathrm{~mm}$ and $<5 \mathrm{~cm}$ ). Among vertebrate macroremains, we distinguish body fossils (i.e. bones and teeth), and ichnofossils, resulting from vertebrate activity (i.e. tracks in sediments, traces on bones and coprolites). Among vertebrate body fossils, we further distinguish two kinds of macroremains based on their identification. Identified specimens are identified both taxonomically and anatomically (NISP, number of identified specimens $=7152$; Table S2). Unidentified specimens are unidentified taxonomically and/or anatomically (mainly ornithomimosaur bone 

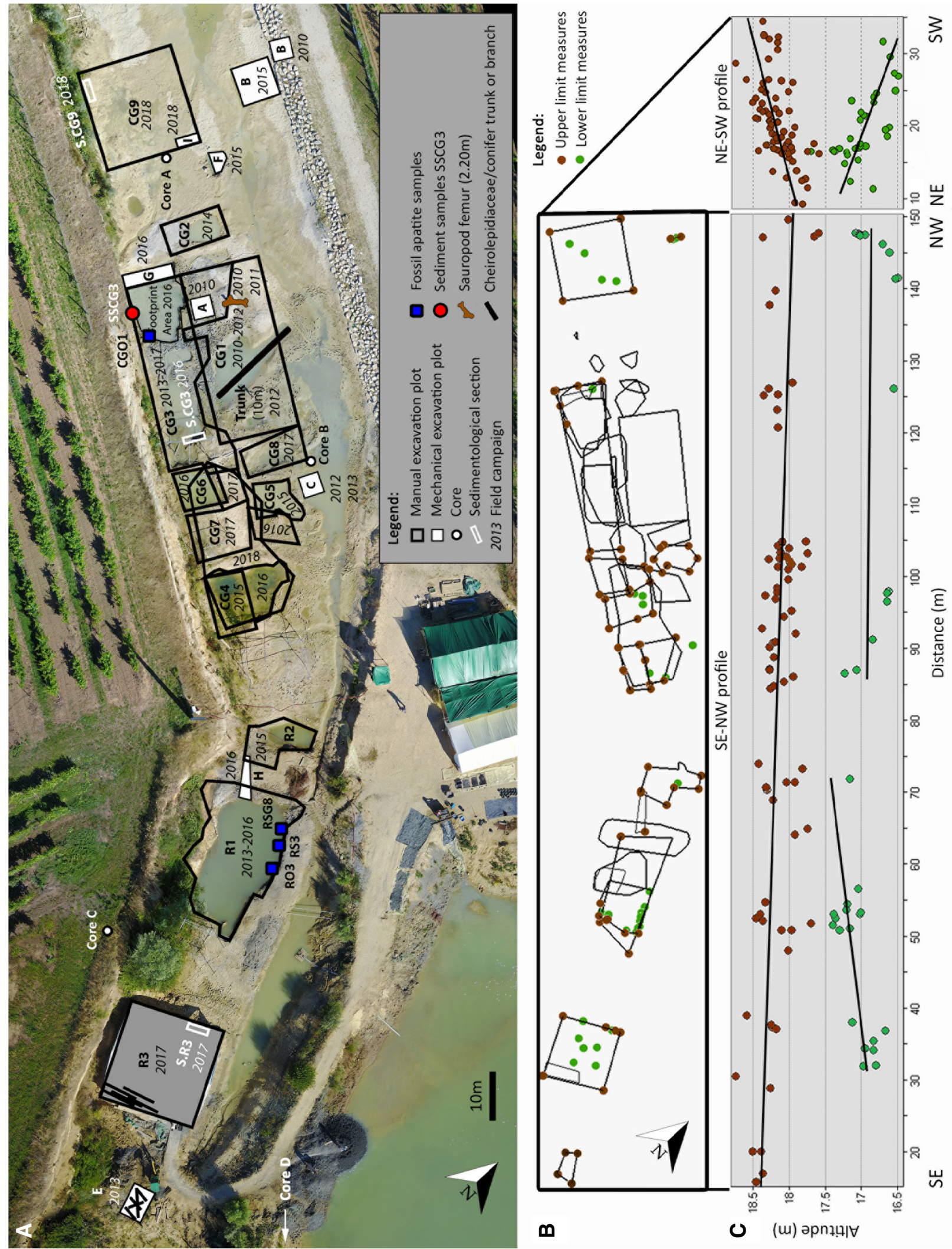

Fig. 2. Palaeontological excavation plots and vertical profiles at the Angeac-Charente site. A, aerial view of the Angeac-Charente site showing the location of manual (R1-3 and CG1-8) and mechanical (A-I) excavation plots, origin of drill cores (Core A-C), sedimentological sections (see Fig. 3), samples for geochemical analyses (see Fig. 5) and some remarkable fossils (July 2017 drone photo courtesy of D. Abit). B, map of the Angeac-Charente locality. C, SE-NW and NE-SW vertical profile plots of lower and upper limits of the bonebed. 
splinters and sauropod bone pebbles, turtle osteoscute fragments and crocodile osteoderm fragments; NUSP, number of unidentified specimens $=66,609$ between 2010 and 2017; Table S2). Identified specimens (except isolated crocodile teeth), unidentified specimens $\geq 15 \mathrm{~cm}$ as well as some other fossils depending on the current scientific interest (i.e. coprolites, mollusc moulds, track casts) have been inventoried and mapped. The other fossils have neither been inventoried nor mapped. However, they have been systematically collected, washed, counted and sorted by size $(<5 \mathrm{~cm}, 5-10 \mathrm{~cm}$ and $>10 \mathrm{~cm})$, field campaign year, plot and, for the 2010 and 2011 data, facies of provenance.

\section{Results}

\section{Geology}

Sedimentology. - Based on the first mechanical excavation and the first two excavation campaigns (Fig. 2, Mechanical excavation plot A), Néraudeau et al. (2012) made a first sedimentological description of the bonebed. New data from the following seven field campaigns give a clear picture of the sedimentology, especially insights into vertical and lateral variations of lithology and thickness (Figs 2,3). The previously defined lithological units (An 1-4 belonging to the bonebed and An 5 underlying the bonebed) of Néraudeau et al. (2012) and then used by Benoît et al. (2017), Polette et al. (2018) and Gônet et al. (2018) are no longer applicable. We have renamed and numbered from the bottom upwards instead of top-down, as geologist usually work from the older to the more recent (Table S3). An 5 has been named Unit 1 . We have added a previously unseen unit at the base of the bonebed (Unit 2). An 4 has been named Unit 3. The two units An 2 and An 3 have been grouped in a single unit that may considerably and progressively vary laterally and vertically (Unit 4). An 1, a fine white to greyish sands unit, was only observed in the first excavation so we do not employ this unit. Thus, we propose new definitions of the units (Units 1 to 4), modified after Néraudeau et al. (2012).

Unit 1 is $80 \mathrm{~cm}$ thick. It is a green clay rich in white, calcareous, sub-angular $1 \mathrm{~mm}$ to $10 \mathrm{~cm}$ scale clasts (Fig. 3). These sub-angular, calcareous clasts are locally reworked from a nearby source, as similar limestones deposit, dating from Tithonian, has been found from a nearby outcrop located a few hundreds of meters from Angeac-Charente site. This unit is devoid of fossils.
Units 2-4 compose the bonebed. It is a mostly dark-grey clay lithosome interrupted by banks, lenses and clasts of various sizes. It is 1.5 to $2 \mathrm{~m}$ thick (Fig. 3). It is thinner in the centre of the site (CG4, R2) and thickens towards the SE (R3), NW (CG9) and SW (Fig. 2B, C).

Unit 2 is $10 \mathrm{~cm}$ thick. It is a matrix-supported (sandy clay) rock with wood pieces, broken bones and abundant identified vertebrate microremains (Fig. 3). It is deposited discontinuously on the underlying Unit 1 and contains rip up calcareous sub-angular $10 \mathrm{~cm}$ scale clasts, abundant $\mathrm{mm}$ to $\mathrm{cm}$ scale carbonate clasts, as well as green folded clay laminae reworked from the underlying Unit 1 . This unit corresponds to a first high-energy deposit of the system and is present at least at the base of the R3 and CG9 plots.

Unit 3 is 40 to $140 \mathrm{~cm}$ thick. The sediment ranges from silty to sandy, dark-grey to brown, soft clay assemblage with occasional sets of horizontal laminae of light grey to green clay and interrupted by several $1 \mathrm{~cm}$ - to $1 \mathrm{dm}$-scale coarse sediment levels or lenses (Fig. 3). The clay is rich in large, well-preserved dinosaur bones and sections of trunks or branches of trees as well as small plant cuticles and branches. Lenses are several $\mathrm{cm}$ to several $\mathrm{dm}$ thick and composed of various clasts such as white soft calcareous $1 \mathrm{~mm}$ - to $1 \mathrm{~cm}$-scale wood pieces and vertebrate remains (Fig. 3). In 2014, a large lens in Unit 3 clay of R1 plot yielded numerous vertebrate macroremains, including a near-complete turtle shell and abundant vertebrate microremains (R. Allain, R. Vullo, L. Rozada, J. Anquetin, R. Bourgeais, J. Goedert, M. Lasseron, J. E. Martin, A. Pérez-Garcia, C. Peyre de Fabrègues, R. Royo-Torres, D. Augier, G. Bailly, L. Cazes, Y. Desprès, B. Gomez, F. Goussard, T. Lenglet, R. Vacant, Mazan, J.F. Tournepiche, unpublished data; Gônet et al. 2018). Reworked white calcareous clasts and green folded laminae (convolute lamination), originating from the underlying Unit 1 and Unit 2, are present at the base of Unit 3. Their number decreases towards the top of the section. They probably result from ascendant movements and fluid escape during the compression of sediments (Allen, 1982). Soft-sediment deformation structures linked to the overlying unit are also present (Fig. 4). They are convolute lamination and detached pseudonodules of clayey to silty sands sunk from the Unit 4. They indicate a liquefaction of the clay (Kuenen, 1953; Allen, 1982). The pseudonodules likely represent load charges or balls and pillows structures. They are related to gravitational instability of vertical profiles of sands deposited on underlying watery mud and/or trampling (Fuchs 1895; 

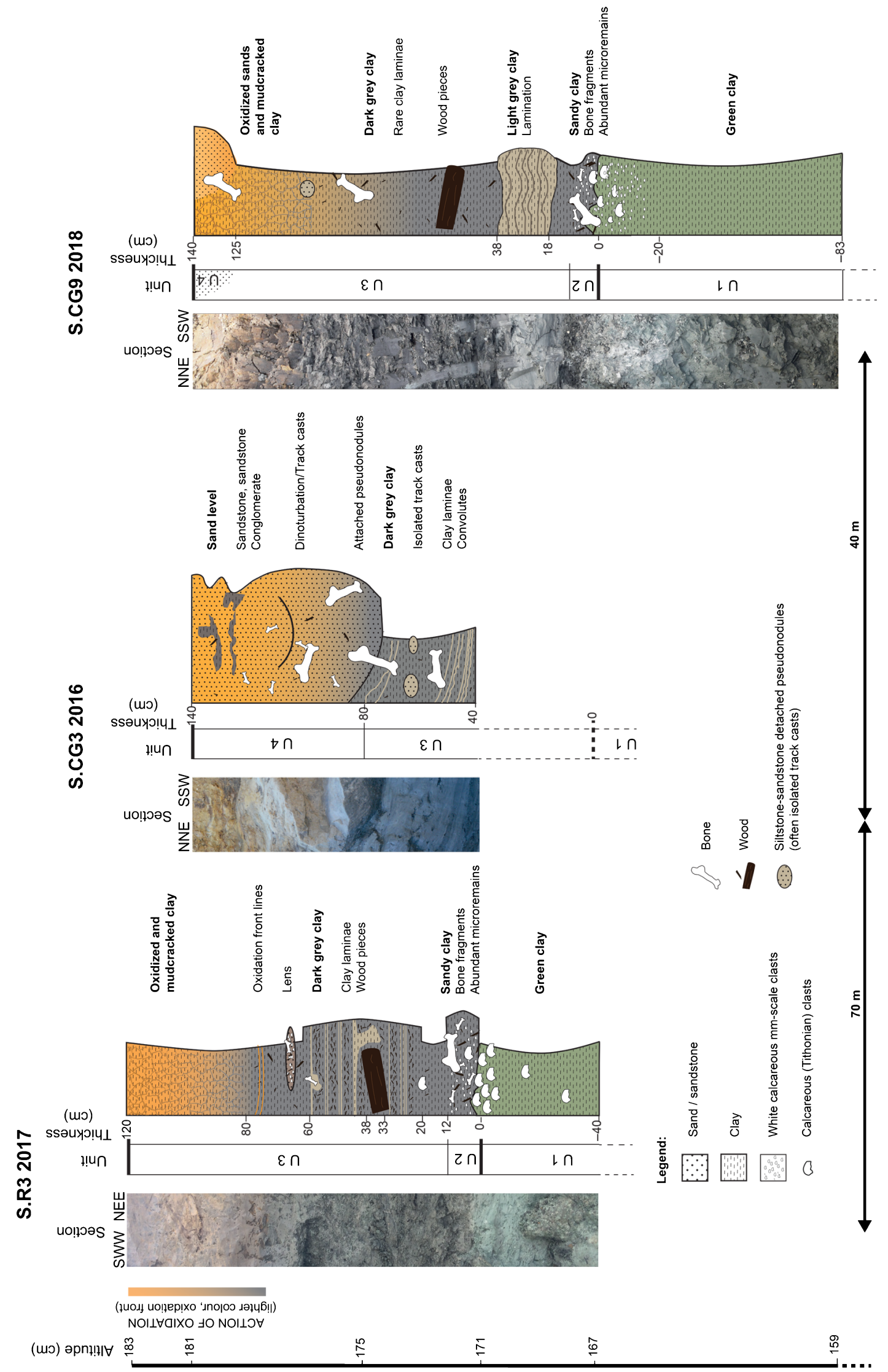
Fig. 3. Angeac-Charente site lithostratigraphical sections of R3, CG3 and CG9. Section locations are shown in Figure 2. The vertical position of the three sections is correlated based on altitude above mean sea level of France (vertical coordinate system NGF_IGN69). The thickness is measured above and below the Unit 1/Unit 2 limit, which marks the end of the bonebed. Horizontal arrows indicate the distance between the sections. Abbreviation: U, Unit. Pictures by L. Cazes, MNHN.

Macar 1948; Kuenen 1953; Potter \& Pettijohn 1963; Allen 1982; Campos-Soto et al. 2017). Some of these 'pseudonodule-like' structures have been identified as isolated dinosaur track casts (see below; Fig. 3). The upper part of the unit (about $40 \mathrm{~cm}$ from the top of the bonebed) is brown and mudcracked with cracks infilled by orange clay, and present successive orange oxidation lines.

This unit is dominant in the bonebed, and it is present all along the site. The R2, R3 and CG9 plots contain less plant and bone fossils but include partly articulated specimens (two turtle shells at R3, one sauropod pelvic girdle at R2 and one crocodile at CG9). Cheirolepidiaceae wood accumulations occur locally, such as the SW-NE oriented trunks and branches, in the upper part of R3 (Figs 2A, 6A, B), and the randomly tangled branches from the mechanical excavation of 2013 (Figs 2A, 6C). By contrast, R1 plot contains bone fossils in remarkably higher quantity but of poorer quality of preservation. They mostly consist of unidentifiable sauropod bone fragments abraded during hydraulic transport.
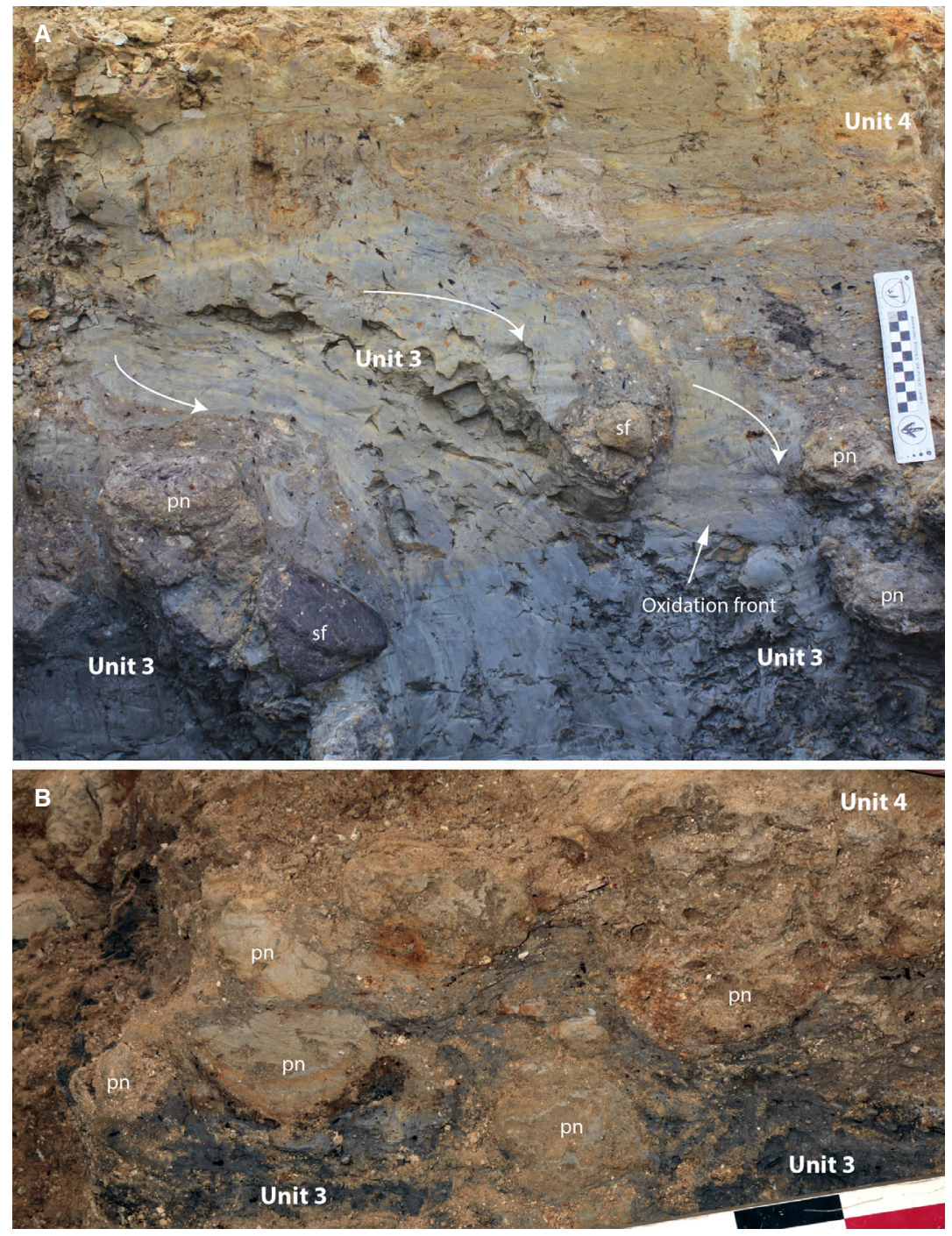

Fig. 4. Angeac-Charente deformation structures. A, CG5 2015 section that reveals the convolute lamination in Unit 4 sands and Unit 3 clay (curved arrows), as well as sauropod bone fragment (sf) and attached pseudonodules (pn) from Unit 4 sunk into the underlying Unit 3 clay. Scale bar: 1 unit $=1 \mathrm{~cm}$. B, a section from CG1 2011 showing detached pseudonodules (pn) of soft sands (from Unit 4) in Unit 3 clay. Scale bar: 1 unit $=5 \mathrm{~cm}$. Pictures: L. Rozada, MNHN (A) and R. Allain (B). 

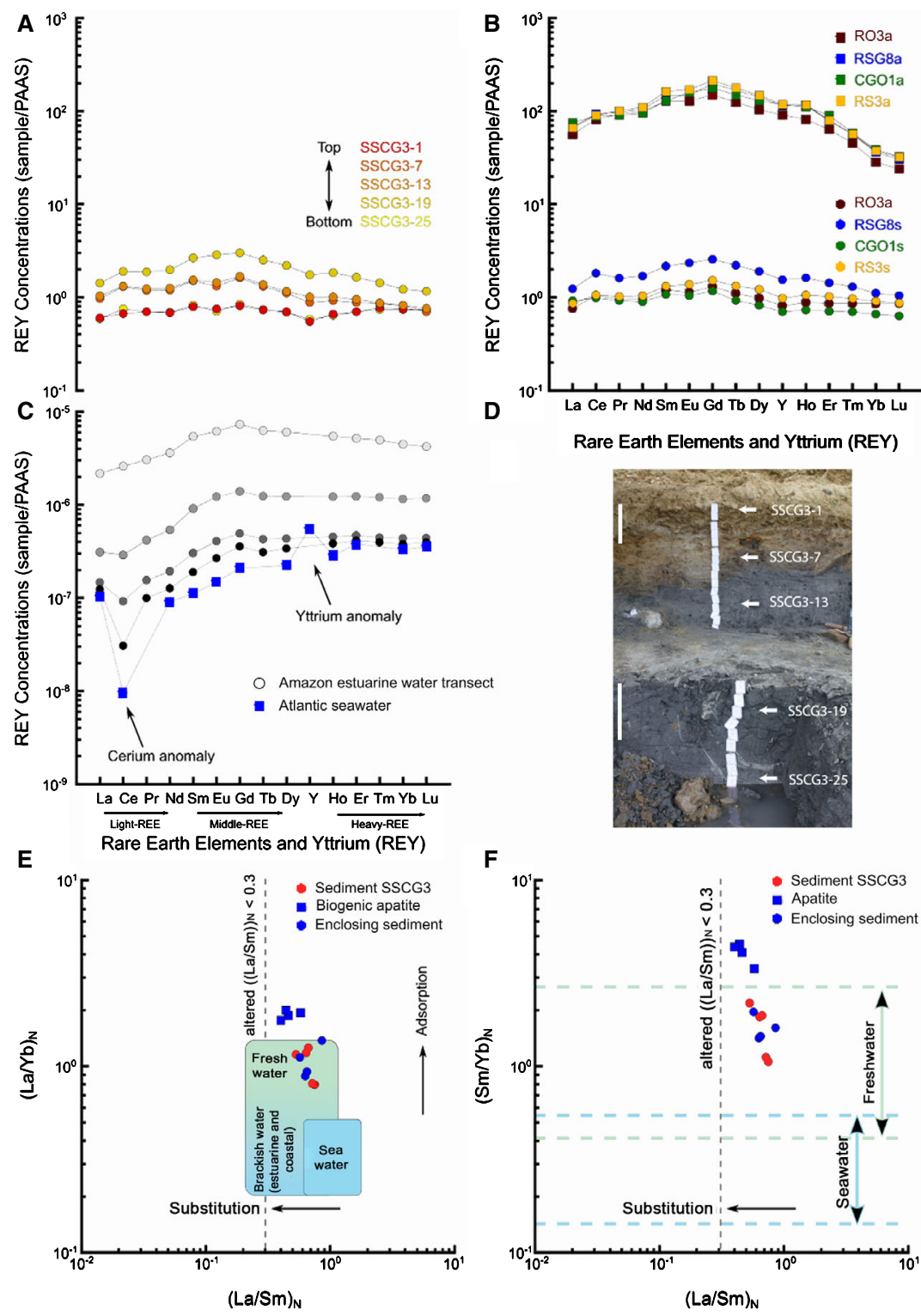

Rare Earth Elements and Yttrium (REY)
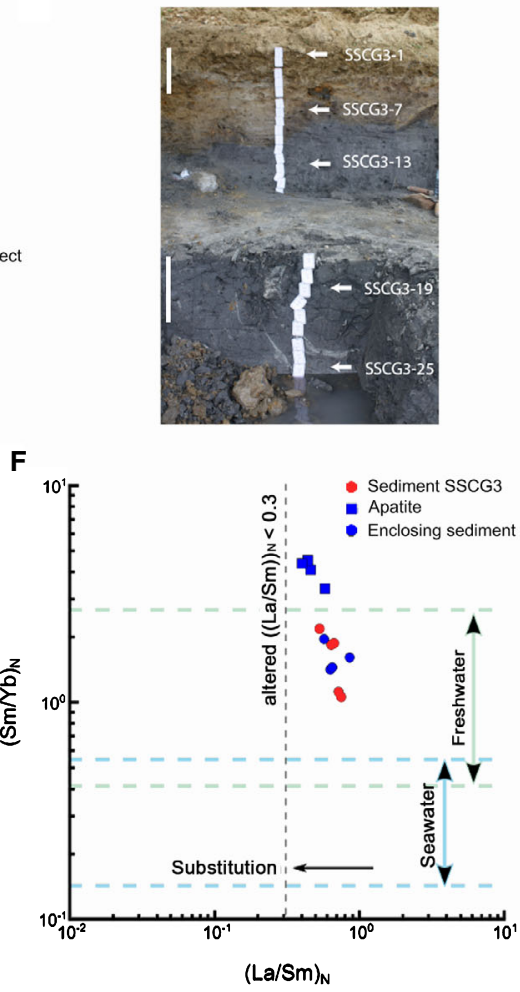

Fig. 5. PAAS-normalized REY patterns of sediments and fossil biogenic apatites from the Angeac-Charente bonebed. A, PAAS-normalized REY patterns of sediments from the top (SSCG3-1) to the bottom (SSCG3-25) of the bonebed. B, PAAS-normalized REY patterns of fossil biogenic apatites (squares) and their enclosing sediments (circles). C, PAAS-normalized REY patterns of different waters from an Amazon estuarine transect (light grey to dark circles; data from Rousseau et al. 2015) evolving towards typical Atlantic seawater pattern (squares; data from Bau \& Dulski 1999). Note the progressive Heavy-REE enrichment and the development of typical negative and positive anomalies for Cerium and Yttrium, respectively. D, pictures of the lithostratigraphical section S.CG3 2015 with vertical series of sedimentological samples SSCG3-1:25 Scale bars: $25 \mathrm{~cm}$. E-F, PAAS-normalized La/Sm vs. La/Yb (E) and La/Sm vs. Sm/Yb (F) of fossil biogenic apatites (squares) and sediments (enclosing sediment of apatite samples and sediments collected across the whole stratigraphical section SSCG3; circles) of Angeac-Charente bonebed. Arrows indicating substitution and adsorption as well as the different domains or limits for freshwater, brackish water and seawater are from Reynard et al. (1999).

Unit 4 is $1 \mathrm{~cm}$ to $1 \mathrm{~m}$ thick. It is a yellow to light-grey, lithified clayey and silty sand that sometimes grades laterally into sandstone and indurated calcite-cemented conglomerates (Fig. 3). These sediments are rich in randomly distributed and orientated vertebrate remains. Deep 3-D and '4-D' (sensu Cobos et al. 2016) dinosaur track casts are present at different levels within this unit and at its lower boundary. Numerous soft-sediment deformation structures are present. Laminae, when present, are sub-horizontal at the top of the unit, and progressively more folded towards the base. The lower boundary with the Unit 3 can be diffuse, with attached pseudonodules sinking in the underlying Unit 3 (Fig. 4). The upper part (about $40 \mathrm{~cm}$ from the top of the bonebed) is oxidized and presents a lighter coloration (yellow to orange) and successive orange oxidation lines. 


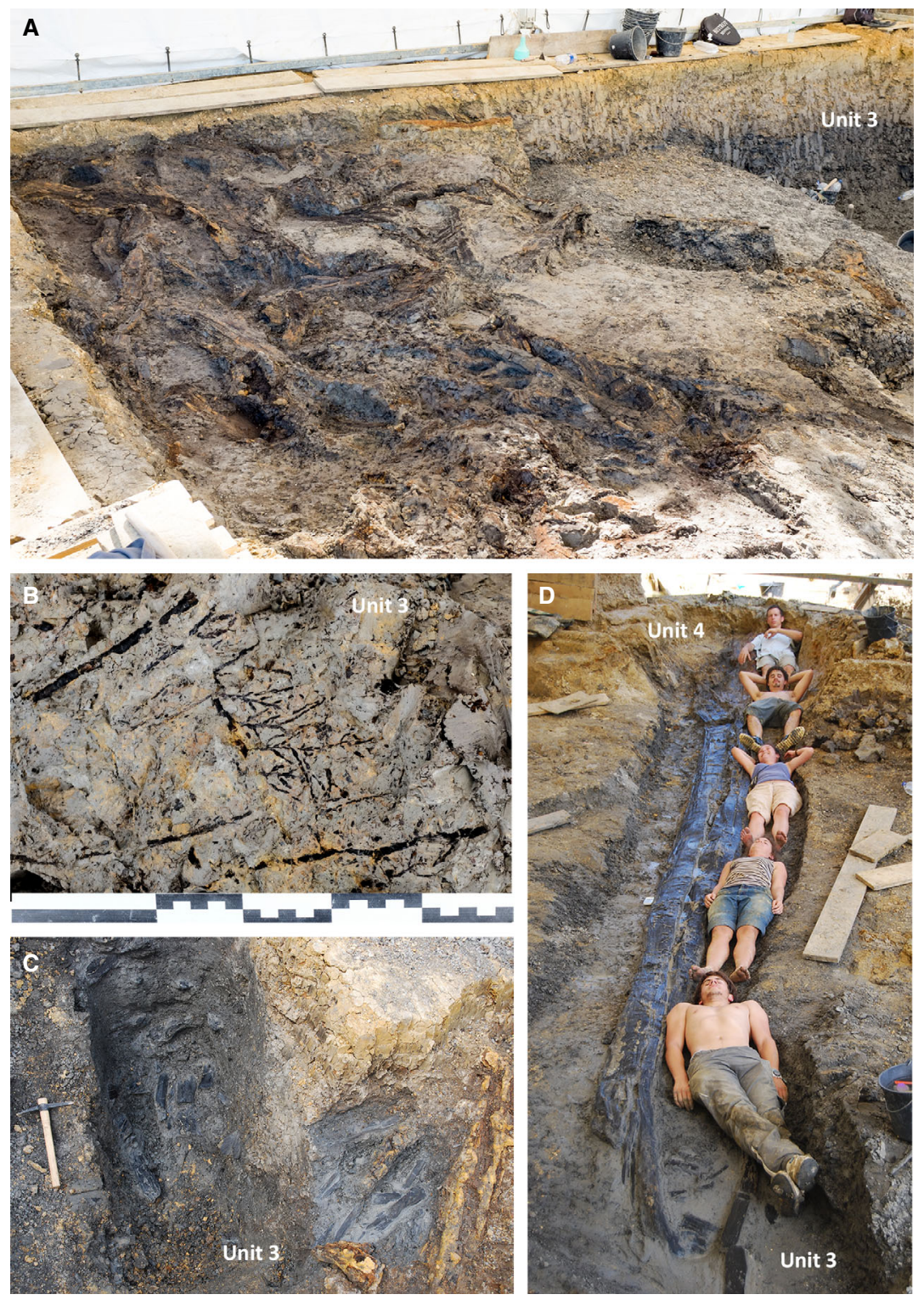

Fig. 6. Plant fossils and accumulations. A, SW-NE oriented Agathoxylon trunks and branches in the upper sediments of R3 plot (Fig. 2A). B, details from A, well-preserved branches. C, randomly tangled long Agathoxylon branches in the 2013 mechanical excavation (Fig. 2A). D, a >12-m-long Agathoxylon trunk (ANG 12-1986; see Fig. 2A to get an idea of the scale). Scale bar: 1 unit $=1 \mathrm{~cm}$. Pictures: L. Bocat (A, B), R. Allain (C, D).

This unit is thicker in the central zone of the site (CG1-7) and towards the South, while it progressively thins towards the SE, SW and $\mathrm{N}$ and becomes absent in R1-3 and the extreme NW of CG9 (Fig. 3). It is sometimes overlain by clay (Unit 3). Fossils are abundant in this central zone (Fig. 7), including a remarkable $>12$-m-long Agathoxylon trunk (Fig. 6D) and a 2.20-m-long sauropod femur (Fig. 7F; Néraudeau et al. 2012).

The bonebed is overlain by alluvium, marked basally by a well defined erosional surface, deposited by the Charente palaeoriver at the beginning of the Late Pleistocene. The erosion by the Charente palaeoriver is at the origin of the erosion, exposure and probably consecutive depressurization and/or drying up and oxidation of the upper part of the bonebed (Fig. 3).

Unit 2, Unit 3 and Unit 4 have the same palaeontological content. Moreover, several long bones intersect vertically the whole lithology of the bonebed and fragments of the same bone, as well as bones in close association, are spatially distributed across the vertical section (Figs 3, 7A-B, D-F). Notably, the different coloration of the cortical surface of bones (even within same bone) is due to different degrees of oxidation of the enclosing sediment (Fig. 7B). All these observations suggest a coeval deposition of the units 2 to 4 , and a continuous deposition from sandy clay, clay to sands. It implies a progressive change of facies 

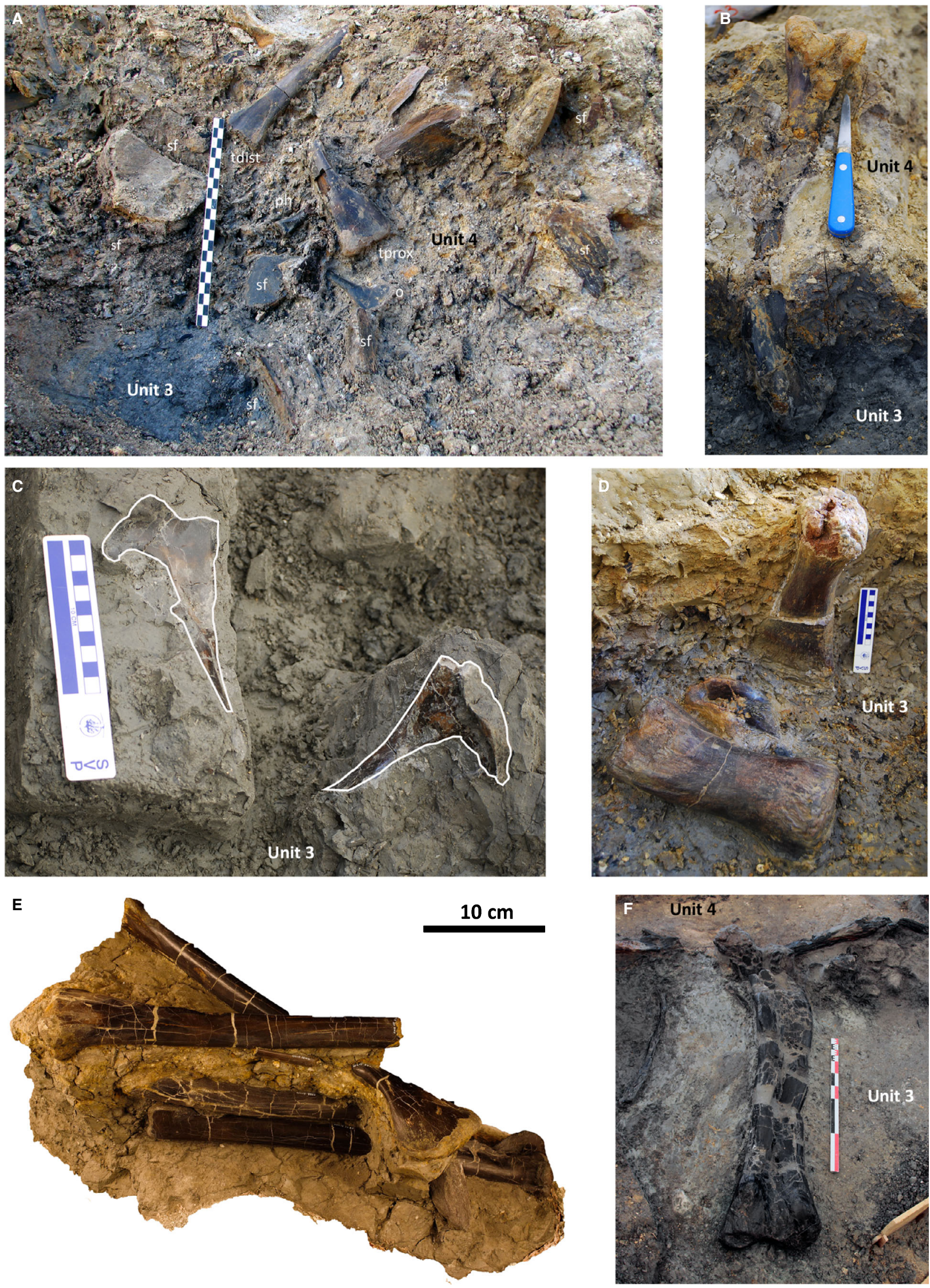
Fig. 7. Vertebrate macroremain body fossils. A, bone accumulation from CG1 2010 plot: ornithomimosaur fragments (o), two fragments of an ornithomimosaur right tibia (tdist, distal part, ANG 10-24 and tprox, proximal part, ANG 10-25), one complete ornithomimosaur phalanx (ph) and numerous sauropod bone fragments (sf). B, ornithomimosaur femur in vertical position in CG1 2011 plot, crossing the whole stratification (ANG 11-0811). The different coloration of the cortical surface of the bone is a function of varying oxidation of enclosing sediment. C, close association of right (ANG 12-1645) and left (ANG 12-1646) ornithomimosaur pubis from CG1 2012 plot. D, close association of two sauropod metacarpals from CG1 2012 plot (ANG 12-1832 and ANG 12-1830). E, accumulation of three ornithomimosaur left tibiae of different sizes (one complete; ANG 15-3811, and two fragments; ANG 15-3810 and ANG 15-3833) and one femur from CG3 2015 plot (ANG 15-3832). F, 2.20-m-long sauropod femur from CG1 2010-2011 plot (ANG 10-400). Scale bar: $1 \mathrm{unit}=1 \mathrm{~cm}$. Pictures: J.F. Tournepiche (A), R. Allain (B, C, D), P. Blanchier (E), L. Cazes (F).

from a short high-energy sand clay deposit (Unit 2), clay of decantation (Unit 3) towards a sand/conglomerate deposited under higher hydric energies (Unit 4). The progressive flooding of the swamp is consistent with the increase in abundance of verrucate spores in the upper section of the bonebed (Polette et al. 2018).

Geochemical data. - As stated by Néraudeau et al. (2012), the presence of smectites in the mineral clay fraction indicates that the whole lithological column has been weakly altered by diagenesis. This is in good agreement with the $(\mathrm{La} / \mathrm{Sm})_{\mathrm{N}}$ ratios in sediments and fossil biogenic apatites which are all higher than 0.3 (Table S1; Fig. 5E, F), suggesting that the early diagenetic REY pattern has not been modified by subsequent diagenetic stages and therefore represents the original burial conditions (Reynard et al. 1999).

Overall, sediment and fossil biogenic apatite samples show similar patterns with a slight enrichment of Middle-REE $\left((\mathrm{La} / \mathrm{Sm})_{\mathrm{N}}<1\right.$; Table S1). Sediment samples do not present a significant enrichment relative to the post-Archean Australian Shale (PAAS), which was used for normalization. On the contrary, apatites are strongly enriched relative to the PAAS, up to about a hundred times more (Fig. 5B). The total REE concentration ( $\Sigma$ REE) ranges from $123.83 \mathrm{ppm}$ to $343.88 \mathrm{ppm}$ for the sediments and from 15,368.18 ppm to $17,762.97 \mathrm{ppm}$ for fossil biogenic apatites (Table S1).

The REY patterns of the sediment samples collected along the whole bonebed section (SSCG3-1; 7; $13 ; 19 ; 25)$ and associated to biogenic apatite (CGO1s; RO3s; RS3s; RSG8s) are similar and show a slightly positive Cerium anomaly (except for SSCG31 and SSCG3-19, which are slightly negative; Fig. 5A; Table S1). The Y/Ho ratios are also similar and close to that of PAAS. This confirms that all the sediments were deposited under similar fluid chemistry conditions, but also suggests poorly oxygenated conditions in the depositional settings (Lawrence et al. 2006). Therefore, as stated above, the different degrees of oxidation of the sediments (orange/brown vs dark clay) are merely a recent artefact of the Charente palaeoriver system and cannot be interpreted as time-different stratigraphical units based on sediment colour.
This is also confirmed by the REY patterns of the four fossil biogenic apatite samples (CGO1a; RO3a; RS3a; RSG8a), which are overall similar to the one recorded by their enclosing sediments, but displaying significantly higher $(\mathrm{La} / \mathrm{Yb})_{\mathrm{N}}$ ratios $(t$-test; two-tailed $P$-value $=0.0038$; Fig. 5E). This reflects their relative depletion for the HREE compared to sediments of the burial environment and is coherent with the fractionation mechanism of REY observed in terrestrial systems (Braun et al. 1993, 1998; Trueman 1999).

This argues in favour of a coeval burial and fossilization of sediments and bones in the same local depositional environment with limited time averaging of vertebrate remains concentration, rather than a reworking of some bones from a previously deposited sediment layer or transported in from another depositional environment. Even the sauropod bone pebble (RSG8a), that was transported after fossilization process begun (as shown by observations of abrasion of sauropod bone pebbles), has REY pattern similar to those of the fresh ornithomimosaur caudal vertebra (RO3a) and sauropod diapophysis (RS3a). This indicates that the sauropod bone pebbles underwent the same early diagenetic history as the ornithomimosaur bones.

\section{Palaeontology}

Macroremains comprise plants, molluscs and vertebrate fossils. Plant macroremains comprise mainly trunk and branches of Agathoxylon Hartig, 1848, a Cheirolepidiaceae tree (Fig. 6; Néraudeau et al. 2012). Mollusc macroremains comprise numerous well-preserved moulds of freshwater unionoid bivalves and a few gastropod moulds referred to Viviparidae (Néraudeau et al. 2012).

\section{Vertebrate body fossil macroremains}

Fossil size. - To assess the relative proportions of macrofossils and microfossils of vertebrate body fossil macroremains, we measured and counted each identified and unidentified collected specimen. Only the 162 NUSP that have been anatomically identified but taxonomically unidentified, have not been measured and counted in this analysis. Among the 
73,144 counted fossils, 19,583 (27\%) are longer than $5 \mathrm{~cm}$ (macrofossils) and 53,561 (73\%) are smaller than $5 \mathrm{~cm}$ (microfossils; Table S4). The microfossils consist primarily of sauropod bone fragments showing various stages of abrasion ranging from splinters to bone pebbles (44,609 NUSP, $83 \%$ of microfossils) and ornithomimosaur bone splinters (1014 NISP, 4918 NUSP; $11.08 \%$ of microfossils; Table S4). Notably, the proportion of microfossils is probably overestimated because of the artificial fragmentation of unidentified bone fragments during sorting, washing, storage and counting in the field. Thereby, according to Eberth et al. (2007), the locality is classified as a mixed bonebed.

Fossil density. - We counted the number of vertebrate macroremains systematically collected from 2010 to 2017 (total body fossils $N=68,726$ and coprolites $N=3123)$ in each plot of the excavated area $\left(724 \mathrm{~m}^{2}\right.$ in total; Table 5). Other fossils such as track casts, molluscs and plant remains are not included in the count because their collection was not systematic, depending on the year, plot and scientific interest. Vertebrate macroremains found outside of the excavation area and the bonebed units are likewise excluded from the count. Overall, the mean fossil density in Angeac-Charente is high, with 99.23 vertebrate macroremains $/ \mathrm{m}^{2}, 94.91$ vertebrate body fossils $/ \mathrm{m}^{2}$ and 4.31 coprolites $/ \mathrm{m}^{2}$ (Table S5).

The vertebrate body fossil density is higher in R1$2\left(140.47 / \mathrm{m}^{2}\right)$ than in R3 $\left(49.88 / \mathrm{m}^{2}\right)$ and CG1-8 (84.92). It is mainly linked to the predominance of sauropod remains in R1 plot (139.81 sauropod body fossil $/ \mathrm{m}^{2}$, with $1.95 \mathrm{NISP} / \mathrm{m}^{2}$; Table S5), which are highly fragmented (122.77 unidentified fragments/ $\mathrm{m}^{2}$ ). Among the plots CG1-8, CG1 (140.94 body fos$\mathrm{sil} / \mathrm{m}^{2}$ ) and CG7 (122.10 body fossil $/ \mathrm{m}^{2}$ ) also have a high vertebrate body fossils density due to the predominance of sauropod (109.27 body fossils $/ \mathrm{m}^{2}$ in CG1 and 88.46 in CG7) and ornithomimosaur remains (19.91 body fossils $/ \mathrm{m}^{2}$ in CG1 and 23.42 in CG7).

It should be noted that these two plots, as well as R3, have been excavated to a greater depth than other plots. Moreover, CG1 was excavated during the first years of exploration of the site (2010-2012), when fossil collection was precise. These factors bias the counts. The low fossil density of other plots is at least in part biased by the excavation of only the upper part of the bonebed (e.g. 9.17 body fossils $/ \mathrm{m}^{2}$ in CG2) and/or the excavation technique allowing a less precise collection of fossils (e.g. 26.71 body fossils $/ \mathrm{m}^{2}$ in CG8; Table S4). Nonetheless, these biases alone cannot explain the general differences of density, which likely reflect genuine taphonomic processes.
Differential taxonomic representation, relative abundance, spatial distribution and preservation. - Vertebrate body fossils collected during all field campaigns, including microremains from sediment screening, belong to at least 38 vertebrate taxa ( $R$. Allain, R. Vullo, L. Rozada, J. Anquetin, R. Bourgeais, J. Goedert, M. Lasseron, J. E. Martin, A. Pérez-Garcia, C. Peyre de Fabrègues, R. Royo-Torres, D. Augier, G. Bailly, L. Cazes, Y. Desprès, B. Gomez, F. Goussard, T. Lenglet, R. Vacant, Mazan \& J.F. Tournepiche, unpublished data). Due to the high number of vertebrate taxa, Angeac-Charente bonebed is multitaxic and present a high diversity (Behrensmeyer 2007; Eberth et al. 2007).

Of the 897 identified remains, turtles represent 13 $\%$ of NISP of vertebrate body fossil macroremains. They are homogeneously distributed throughout the site, ranging from 0.33 body fossils $/ \mathrm{m}^{2}$ in CG2 (potentially underestimated, cf. hereabove) to 5.57 body fossils $/ \mathrm{m}^{2}$ in R1 (Table S5). They belong to three taxa: Pleurosternidae, Helochelydridae and Plesiochelyidae (R. Allain, R. Vullo, L. Rozada, J. Anquetin, R. Bourgeais, J. Goedert, M. Lasseron, J. E. Martin, A. PérezGarcia, C. Peyre de Fabrègues, R. Royo-Torres, D. Augier, G. Bailly, L. Cazes, Y. Desprès, B. Gomez, F. Goussard, T. Lenglet, R. Vacant, Mazan \& J.F. Tournepiche, unpublished data). The Pleurosternidae Pleurosternon bullockii Owen, 1842 is the most abundant, with 730 NISP (84 \% of turtle NISP). Material attributable to Helochelydridae and Plesiochelyidae is rarer (Table S2). Turtle remains are mainly represented by isolated, complete or fragmented shell plates ( 829 of turtle NISP that is $>92 \%$ of turtle NISP and 1605 unidentified small fragments of osteoscutes) and rare bones (Table S2). A well-preserved, near-complete shell of $P$. bullockii was found in 2014 in a lens in R1 (Gônet et al. 2018). Twelve fragments of P. bullockii shells comprising several connected plates have been collected from various loci. In 2017, plates belonging to a nearly complete specimen were found in close association in R3. The near-complete shell (Gônet et al. 2018), ten isolated right epiplastra and several small isolated costal bones provide a MNI of 12 for P. bullockii, representing juveniles to adults.

Crocodiles are represented by 1282 identified remains, corresponding to about $18 \%$ of NISP of vertebrate body fossil macroremains. They are known from numerous isolated teeth $(\geq 82 \%$ of crocodile NISP), osteoderms ( $\geq 11 \%$ of crocodile NISP) and other bones, including numerous skull bone fragments (Table S2). The vast majority of AngeacCharente crocodile teeth have been found with resorbed roots, indicating that they have been shed during the life of the animals (polyphyodonty; Bertin et al. 2018; Edmund 1962; Erickson 1996a; Lubkin 


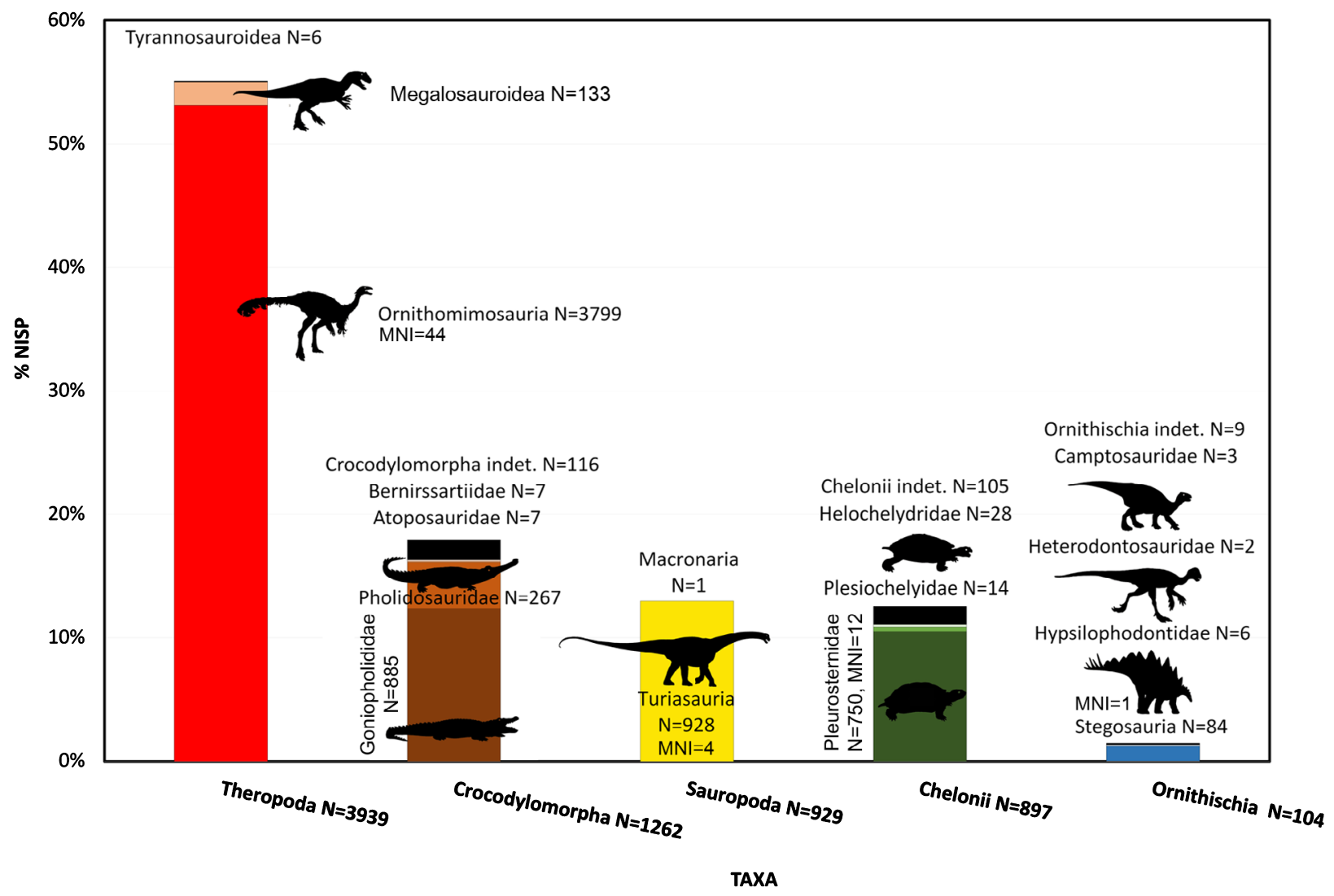

Fig. 8. Relative abundance of vertebrate macroremains. The relative abundance is estimated with the percentage of the NISP for each taxon (Table S2) collected from 2010 through 2017. Ornithomimosaur long bone shaft and rib fragments are included as identified specimens. Abbreviations: indet., indeterminate; MNI, minimum number of individuals; N, number of specimens (bone, tooth or fragment); NISP, number of identifiable specimens. Vertebrate silhouettes after Mazan.

1997; Poole 1961). Crocodile remains belong to at least four taxa : the generalist Goniopholis is the most abundant (69\% of the crocodile NISP), then the piscivorous Pholidosauridae (30 \% of the crocodile NISP) and the small Bernissartiidae and Atoposauridae (the NISP of the two latter is not representative because of the very small size of their teeth that are abundantly found in sediment screening; R. Allain, R. Vullo, L. Rozada, J. Anquetin, R. Bourgeais, J. Goedert, M. Lasseron, J. E. Martin, A. Pérez-Garcia, C. Peyre de Fabrègues, R. Royo-Torres, D. Augier, G. Bailly, L. Cazes, Y. Desprès, B. Gomez, F. Goussard, T. Lenglet, R. Vacant, Mazan \& J.F. Tournepiche, unpublished data). A partial, closely associated skeleton, including a nearly complete skull and mandible, of Goniopholididae was found in CG9.

Dinosaurs present both the highest taxonomic diversity (13 taxa) and the highest abundance considering the number of their identifiable remains (4972 identified specimens, $70 \%$ of NISP; Fig. 8, Table S2). A new, as yet undescribed species of Ornithomimosauria (Allain et al. 2013) is the dominant taxon. It is represented by 3800 anatomically identified bones from every part of the skeleton, constituting $>53 \%$ of NISP (Table S2, Fig. 8). These bones are often broken: only 22 tibiae ( $9 \%$ of the 238 collected pieces of tibiae) are complete or subcomplete (e.g. Fig. 7E). Ornithomimosaur remains are also represented by 5590 anatomically unidentified specimens ( $8 \%$ of vertebrate body fossil NUSP; Table S2), which are mainly small bone splinters from long bone shafts. The whole material shows exceptionally well-preserved cortical surfaces with minute bone ornamentation and muscle scars. Edges on broken bones are sharp (Allain et al. 2011, 2013, 2014; Néraudeau et al. 2012; Rozada 2014, 2017; Rozada et al. 2014). Ornithomimosaur remains are concentrated in the CG1-8 plots (85\% of ornithomimosaur body fossil, density of 13.48 ornithomimosaur body fossil/ $\mathrm{m}^{2}$ ) while the remaining $\left(15 \%\right.$, density of $\left.4.51 / \mathrm{m}^{2}\right)$ are from R1-3. They are mostly found in CG1 (33\%, 19.91 body fossils $/ \mathrm{m}^{2}$ ) and CG3 (37\%, 15.27 body fossils $/ \mathrm{m}^{2}$; Table S5). Ornithomimosaur material represents at least 44 individuals of varying sizes and ages (from juveniles to sub-adults), based on 44 left distal ends of tibiae. The spatial distribution, skeletal 
representation, homogeneous preservation, high number of individuals and age profile of the ornithomimosaur assemblage support a mass mortality event impacting a multiyear juvenile-dominated group suggestive of herding (Allain et al. 2011, 2013, 2014; Néraudeau et al. 2012; Rozada 2014, 2017; Rozada et al. 2014). Similar herding behaviour is known among other dinosaur groups and ornithomimosaur species, such as Sinornithomimus dongi of the Suhongtu site (western Inner Mongolia) in the Upper Cretaceous of the Ulansuhai Formation (Varricchio et al. 2008).

Other theropods, referred to Megalosauroidea (133 NISP, $2 \%$ of NISP) and Tyrannosauroidea (6 NISP, $0.01 \%$ of NISP), are rarer and only represented by isolated teeth (Table S2). As with the crocodiles, most of these are shed teeth (Erickson 1996b) and teeth that broke during feeding (Tanke \& Currie 1998).

Sauropods are known by 930 NISP representing all parts of the skeleton. Based on the femora, at least 4 individuals of a single taxon closely related to the Iberian turiasaurs Turiasaurus and Losillasaurus (Royo-Torres et al. 2006; Royo-Torres \& Upchurch, 2012; Allain et al. 2013) are present. A second taxon, represented by a single abraded tooth, and possibly another one recovered from microremains, could be assigned to a basal Macronaria. Sauropod remains are also represented by an extraordinary high amount of bone fragments (about 58,627), that are $89 \%$ of NUSP (Table S2). They display various stages of fragmentation and abrasion, from splinters to pebbles. Sauropod remains are abundant in the whole site but concentrated in R1 (38\% of vertebrate body fossils, 139.81 body fossils $/ \mathrm{m}^{2}$ ), with sauropod bone fragments showing a higher density (138 $\mathrm{NUSP} / \mathrm{m}^{2}$; Table S5).

Stegosaurs are represented by 84 identified skeletal elements (only $1 \%$ of NISP; Table S2), primarily vertebrae and ribs and a few appendicular and skull bones. Several fragments have been identified based on the peculiar bone ornamentation of stegosaurs. Their number is underestimated because they have not been systematically identified from the fragments representing large-size taxa that are mostly attributed to sauropod. These stegosaur bones probably belong to the same individual as there is no overlap in elements and all bones are from the same area $(71 \%$ of stegosaur NISP have been found in CG4 and CG6 2016 plots, with a density of 0.47 $\mathrm{NISP} / \mathrm{m}^{2}$; Table S5).

Other ornithischian remains are rarer. A camptosaurid ornithopod has been identified from a single femur and two well-preserved isolated teeth, along with hypsilophodontids and heterodontosaurids, represented by eight partially abraded teeth (Table S2).

Due to the high percentage of ornithomimosaurs material that is represented by a wide range of skeletal elements compared with other taxa, the bonebed is classified as monodominant (Eberth et al. 2007).

\section{Vertebrate ichnofossil macroremains}

Three kinds of ichnofossils have been found in Angeac-Charente site: track casts, marks on vertebrate remain surfaces, and coprolites.

Tracks. - Described as 'a succession of 'bowls' thrust into the underlying unit' and 'structures [that] could represent footprints or be the result of trampling', the record of dinosaur tracks in Angeac-Charente sediments have been suspected since 2010 (Néraudeau et al. 2012). Their identification was confirmed during the 2016 field season and is now identified as natural casts of sauropod and stegosaur pes and manus tracks (Figs 9-11). They are abundant in the central zone of the site (CG 1-8), while only a few isolated track casts have been observed in the Unit 3 clay of R1 plot. As stated above, they are observed within the sand-conglomerate bank Unit 4 (Fig. 9A, B), at the contact between Unit 4 and the underlying Unit 3 clay (Fig. 9, 10) and as sandy-siliceous indurated pseudonodules floating in the Unit 3 clay (Fig. 11).

Large $(50 \mathrm{~cm}$ to $>1 \mathrm{~m}$ diameter) natural track casts are abundant at various levels in the sand-conglomerate bank Unit 4 and at the boundary between Unit 3 and Unit 4 in the CG 1-8 plots (Fig. 9, 10). At the contact of units 3 and 4, the deep tracks in Unit 3 clay are infilled by sands of the overlying Unit 4 . Numerous casts preserve the 3-D morphology (Fig. 9 A, C), allowing to identify them as sauropod tracks. Several casts show the imprint of slide marks and grooves formed by the dinosaur skin scales created by the animal pes or manus moving in mud (Figs 9 A, C; Diffley \& Ekdale 2002; Gatesy 2001). Such track casts, recorded under exceptional circumstances, have been called '4-D tracks' by Cobos et al. (2016), as they comprise evidence of distal limb kinematics of the trackmaker by recording the movement of the feet during track-making. Similar preservation of '4D' track casts attributed to theropods and ornithopods have been observed in the late Barremian Rió Alcalá tracksite (Teruel Province, Spain; Cobos et al. 2016).

A sauropod track cast is present above, and in contact with, an in situ broken sauropod ulna (Fig. 10). The orientation of small fragments of the long bone (Fig. 10A, Bone fragments) and Unit 3 

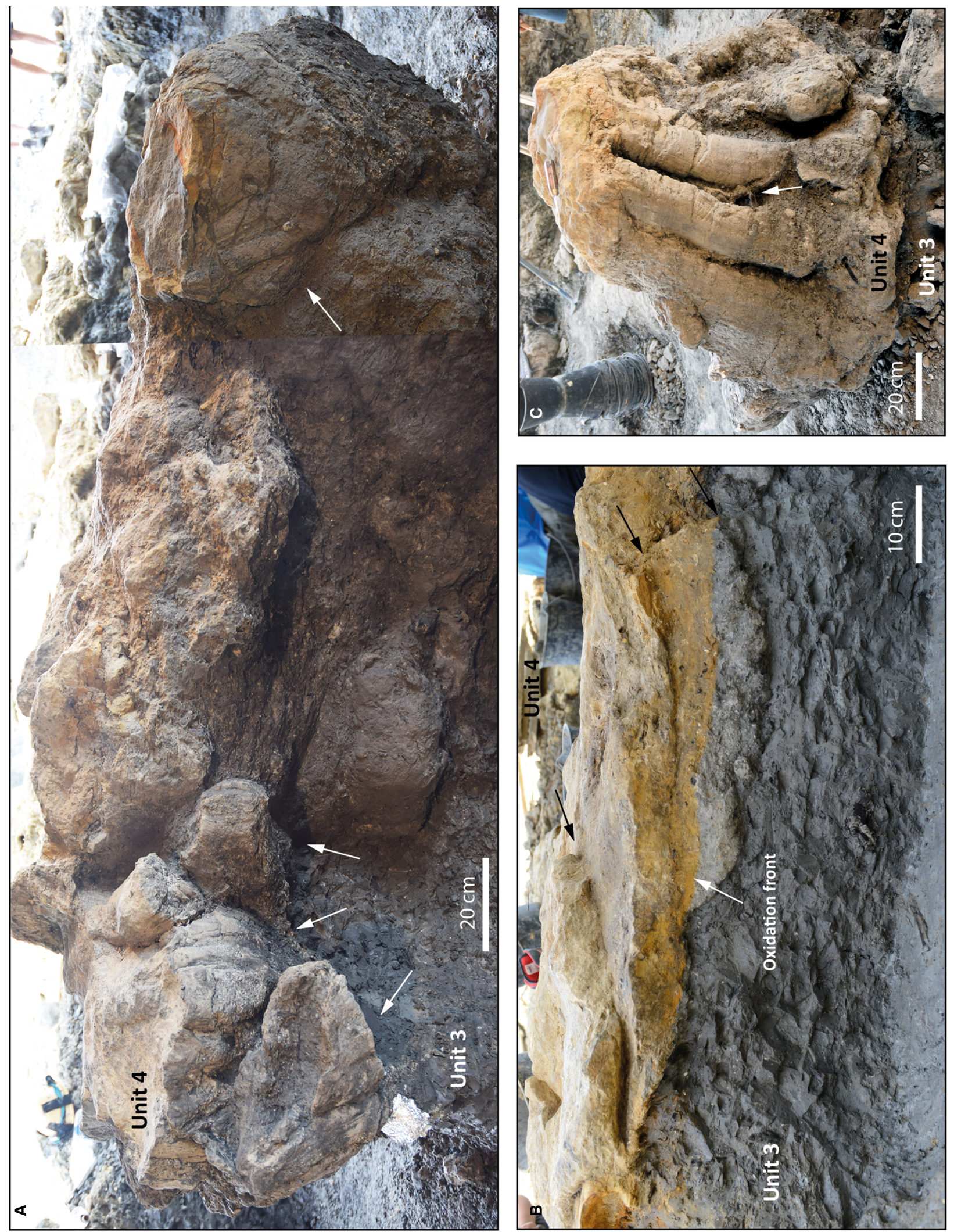

Fig. 9. Sauropod track casts in the central area (CG 1-8) of Angeac-Charente site. A-B, multiple sauropod pes and manus natural track casts in Unit 4 and at the contact between the units 3 and 4 (two combined pictures). A, CG7 2018. Arrows show the casts of the digits, slide marks and grooves. B, CG6 2017. Black arrows highlight the surface of the true tracks (two in Unit 4 and one at the contact between Unit 3 and Unit 4). C, an exceptionally preserved '4-D' track cast from CG7 2018 plot attributed to a sauropod manus preserving digit morphology, slide marks and grooves (ANG 18-6529). Notably, the proximal end of an ornithomimosaur metatarsal is stuck between the two central digit imprints (arrow). The knife on the top of the track cast is approximately $15 \mathrm{~cm}$ long. Pictures: L. Cazes, MNHN (B); R. Allain (A, C). 

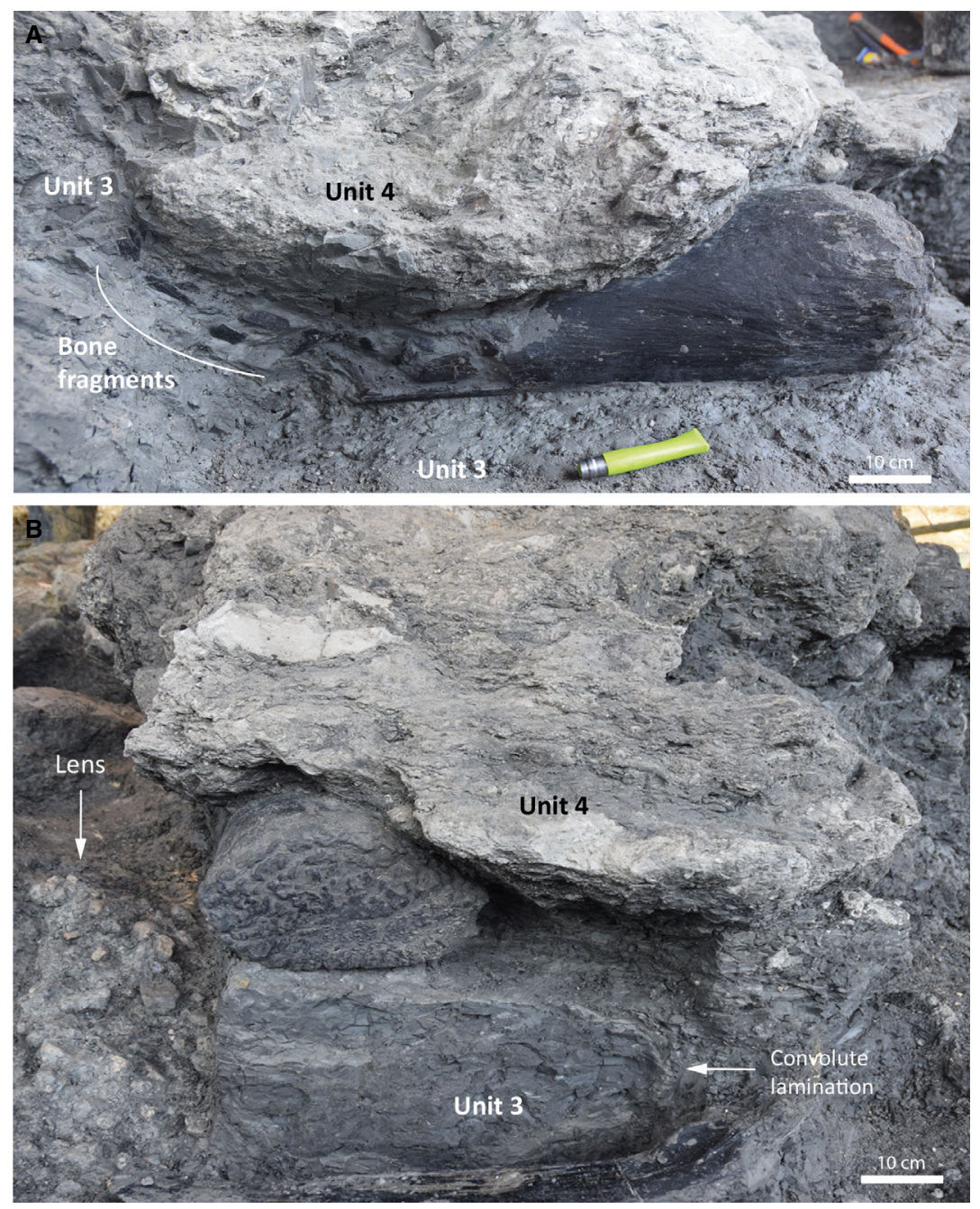

Fig. 10. Exceptional record of a trampled bone (distal part of the sauropod right ulna ANG 18-6487) under the culprit sauropod track (CG 7 plot). A, ulna in posterior view. The culprit track is infilled by Unit 4 sediments, and the bone is in Unit 3. The numerous small bone fragments lined up along the surface of the track highlight the in situ breakage induced by trampling. B, ulna in distal view. Convolute lamination in Unit 3 sediment below the bone highlights deformations in clay induced by trampling. Scale bar in A: $1 \mathrm{unit}=1 \mathrm{~cm}$. Pictures: R. Allain.

clay deformations (Fig. 10B, Convolutes) are oriented parallel to the surface of the track (true track). It is a spectacularly 'instantaneous' preservation of the action of a sauropod pes or manus crushing a sauropod long bone, inducing bone modifications (breakage, displacements and reorientation) and sediment deformation.

More than 126 vertebrate track casts have been identified in the CG3 2016 plot (Figs 2, 11; Rozada et al. 2016; Rozada 2017, L. Rozada, R. Royo-Torres \& R. Allain, unpublished data). They are also present in other plots, such as in CG 1-8 in Unit 3 and Unit 4 , and more rarely in Unit 3 of R1 plot (probably ex situ). They are $1 \mathrm{dm}$-scale rounded silty or fine sandy isolated blocks in dark clay, and numerous examples are distributed in a single bedding plan. Sand probably comes from the overlying Unit 4 . Such unusual preservation of dinosaur tracks has been recorded in the clay quarry in Oliete (Teruel, Spain) from the top of the Albian Escucha Formation (Royo-Torres et al. 2013). The latter, deposited in a coastal plain environment, consists in hundreds of dinosaur track casts found as isolated 'balls' of soft sand within a clay layer overlaid by a grey-sandstone layer. At AngeacCharente, most of those track casts are not well-preserved, but the morphology of the best-preserved ones (pes print sub-triangular to oval in outline, with the internal side slightly concave, and mesaxonic with three digits impressions as short projections or bluntly rounded points; Fig. 11B; L. Rozada, R. Royo-Torres \& R. Allain, unpublished data) allow assignment to the ichnotaxon Deltapodus (Whyte \& Romano 1994; Cobos et al. 2010), attributed to stegosaurian pes and manus tracks (Cobos et al. 2010). 


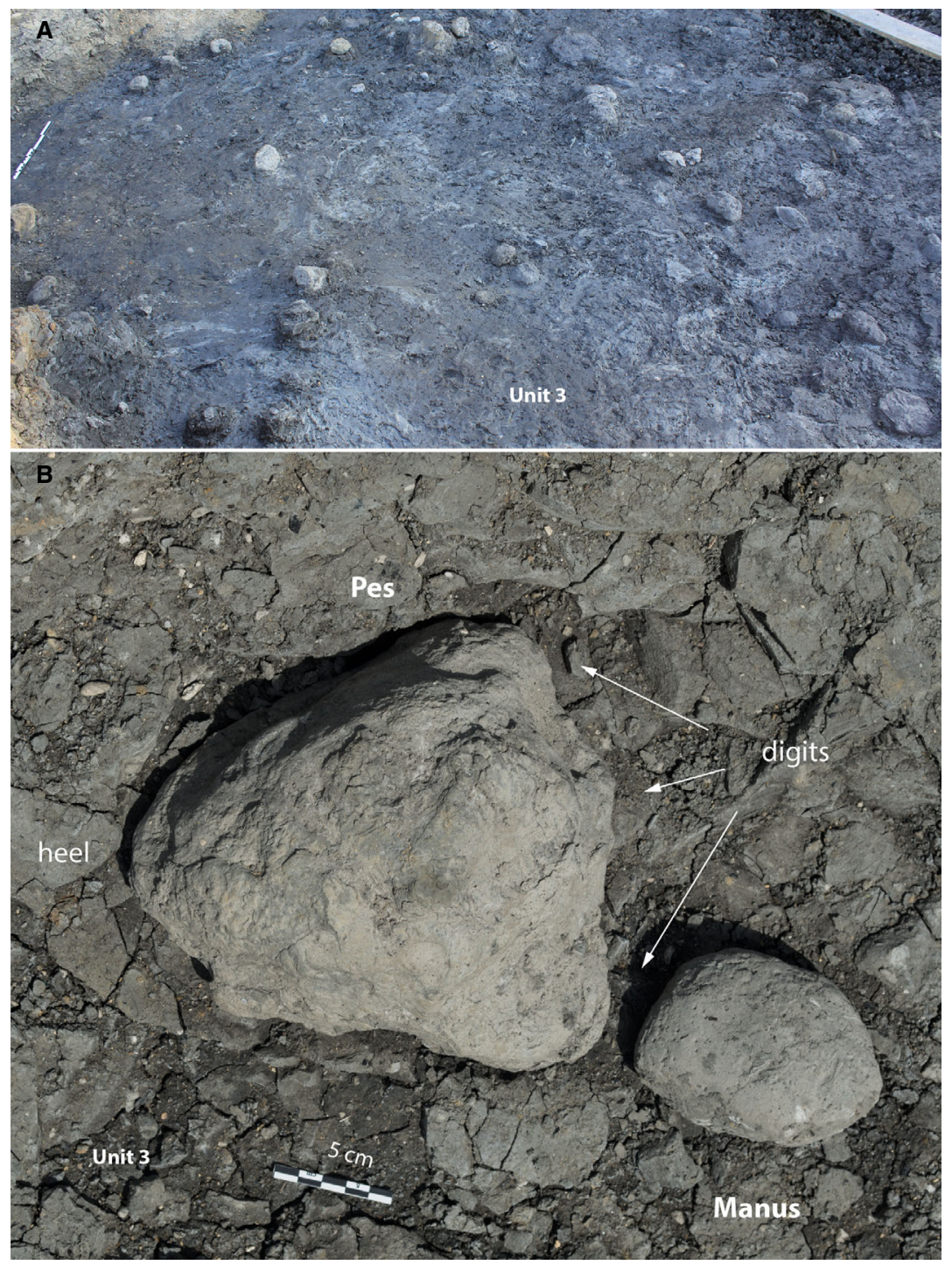

Fig. 11. In situ track casts in Unit 3 attributed to a stegosaurid. A, general view of CG3 2016 plot showing sandstone/siltstone track casts in Unit 3 clay. B, top view of a pair of stegosaur pes (ANG 16 Ep60) and manus (ANG 16 Ep60) track casts. Scale bar: 1 unit $=1 \mathrm{~cm}$. Pictures: L. Cazes, MNHN.

There are about 100 tracks in a range of sizes on a single bedding plane (Fig. 2; track area 2016; Fig. 11 A). Although several pes and manus couples were recognized (e.g. Fig. 11B), no distinct trackways were evident. The spatial distribution and size profile of this Deltapodus ichnoassemblage suggest gregarious habits for Angeac-Charente stegosaurs, as they are in a single bed and in a restricted area (Lockley 1994). These tracks are currently under study to test the gregarious hypothesis.

Traces on bone surfaces. - Marks on the surface of bones are abundant and diverse. Most are on ornithomimosaur bone and turtle shell surfaces and attributed to vertebrate activity, specifically: trampling and crocodile tooth marks (Fig. 12). The exquisite preservation of bone surfaces provides a rich qualitative and quantitative database, including morphology, orientation and distribution of trample and crocodile-bite marks (Rozada 2014; Rozada et al. 2014; Gônet et al. 2018). The traces on other vertebrate remains or resulting from other taphonomic agents (such as insect activity) are more anecdotal.

Crocodile tooth marks are abundant on turtle remains. $>780$ tooth marks have been counted on 238 (that is $94 \%$ ) of the 253 complete or fragmentary osteoscutes observed (material collected between 2010 and 2017; Fig. 12A, B). Crocodile tooth marks on ornithomimosaur bones are less abundant in both the number of marks and the number of marked bones. On the 215 tibial remains observed (from 2010 to 2018 ), only 61 (28\%) have crocodile tooth 


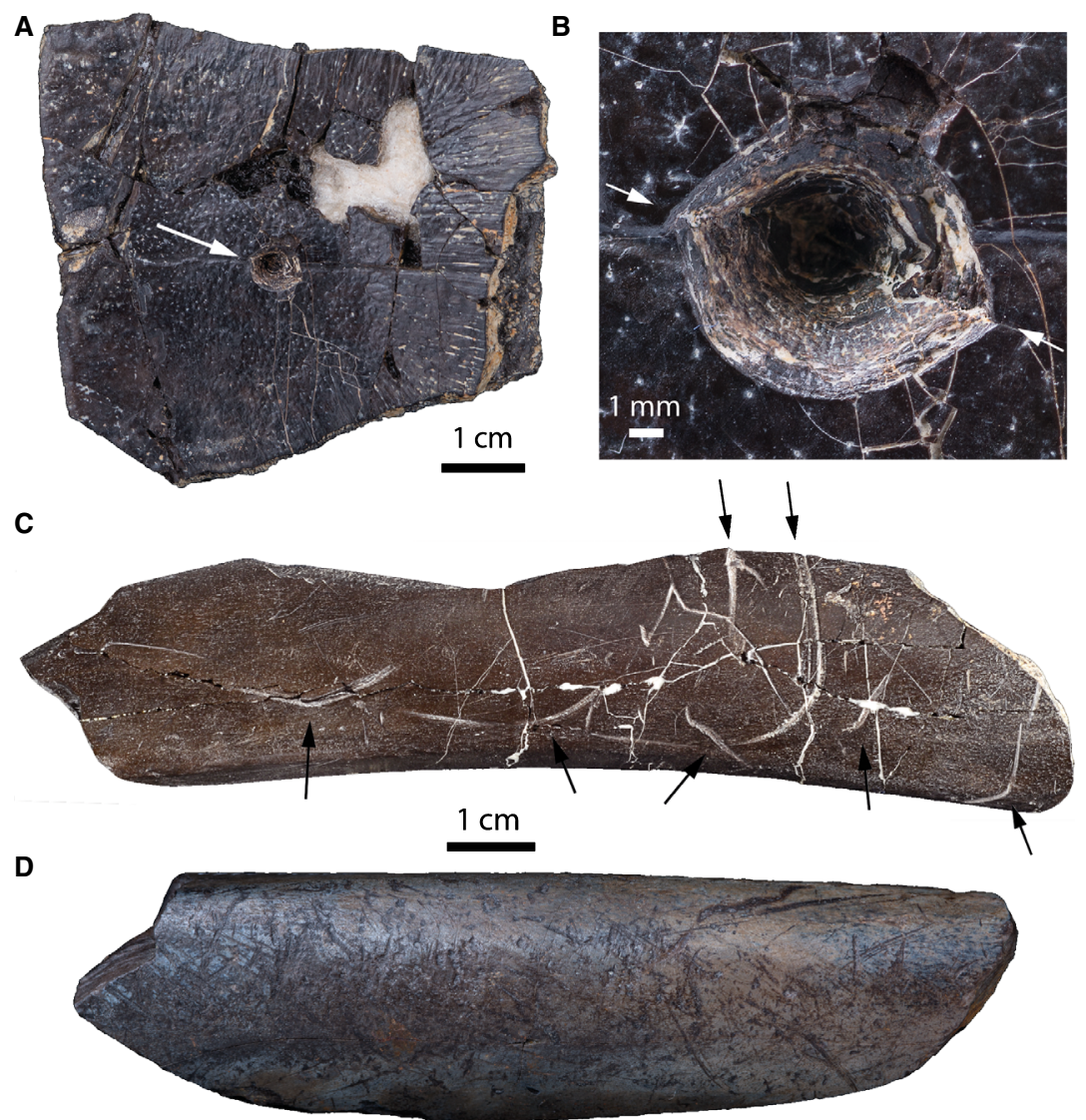

Fig. 12. Surface modifications on Angeac-Charente bone. A-B, bisected puncture attributed to the bite of a Goniopholididae crocodile on a turtle shell plate (ANG 14R-534a). Arrows point at the carinal position. C, hook scores (arrows) recorded on an ornithomimosaur bone splinter (ANG 15-3899). D, multiple trample marks preserved on an ornithomimosaur bone splinter (ANG 15-3761). Pictures: L. Cazes, MNHN.

marks. These include healed or unhealed bisected (Fig. 12A, B) and rounded pits and punctures, straight and hooked scores, drag snags and striations (Fig. 12C; Gônet et al. 2018). Many include fine internal striae from crocodile tooth asperities (Fig. 12 C; Gônet et al. 2018). The size, morphology and spatial distribution of tooth marks are similar to previous descriptions of fossil and actual bone damages attributed to crocodile predatory and feeding behaviour (e.g. Binford 1981; Njau \& Blumenschine 2006; Noto et al. 2012; Fernandez-Jalvo \& Andrews 2016; Njau \& Gilbert 2016). The detailed study of the nearcomplete turtle shell allows us to identify the producer of these marks and its predatory behaviour (Gônet et al. 2018). All features are consistent with the jaws and skull size and tooth morphology of a Goniopholididae crocodile (e.g. presence of carinae on teeth, distance between pits). The crushed peripheral plates, tooth marks on the edges of peripheral plates and the near-complete carapace and plastron, found $1 \mathrm{~m}$ of each other, indicate the use of the nutcracker technique (Milán et al. 2010; Gônet et al.
2018). Future studies of crocodile tooth marks on ornithomimosaur bones will determine if the marks and breaks are due to crocodile predation and/or scavenging. Similar patterns of damages on turtle and dinosaur bones caused by a generalist/opportunistic crocodile inhabiting a wetland environment have been reported in the vertebrate assemblage of the Arlington Archosaur Site (Texas) from the Woodbine Formation (Cenomanian, Upper Cretaceous), deposited in a delta-plain environment (Noto et al. 2012).

Trample marks are abundant on ornithomimosaur bones but are also present on the turtle and more rarely on sauropod remains. Some 205 (92\%) of the 223 observed ornithomimosaur bones (from 2010 to 2012 field campaigns) exhibit trample marks. The marks are fine and shallow, simple or paired, straight or curved isolated stripes (60\% of bones), sets of parallel striations $(60 \%)$, as well as wider and deeper scratches (10\%), often randomly intersected (Fig. 12 D). They are preferentially found on convex, flat or prominent anatomic parts, where siliceous clasts are 
pushed across the cortical surface. These patterns and positions are similar to previously described trample marks created by large animals (Andrews \& Cook 1985; Behrensmeyer et al. 1986; Olsen \& Shipman 1988). To understand the effects of trampling in the soft clay and fine sandy sediments, two exploratory trample experiments were conducted on modern sheep bones in Angeac-Charente sediments (Rozada et al. 2018). The results show similar pattern of morphology, position, orientation and frequency of each kind of trample marks (Rozada et al. 2016).

Coprolites. - About 3320 coprolites (complete or fragmented) were collected from 2010 through 2017. They are 3-D and most (97 \%) are $<5 \mathrm{~cm}$ in length. Most were isolated, but four aggregations of associated 'piles' of coprolites were found. These were not transported and likely represent isolated excretion 'events'. A preliminary study of the size, morphology, contents and surface marks of the best-preserved coprolites (383 collected between 2010 and 2016) has been conducted. Most of the coprolites are not complete (about $91 \%$ ). > 10 morphotypes have been identified. The most abundant are segmented cylinders, which are typically attributed to crocodylomorphs faeces (Fig. 13A; Hunt \& Lucas, 2012; Milán 2012; Barrios-de Pedro et al. 2018). They contain plant and fish and rare turtle and ornithomimosaur remains. Flat and ovoid-shaped morphs are also abundant. These are tentatively attributed to a herbivore based on abundant plant fragments (Fig. 13B; cf. BaghaiRiding \& DiBenedetto 2001; Chin 2007; Ghosh et al. 2003; Prasad et al. 2005). A few small, anisopolar (the terminations are of different morphologies) and wellpreserved cylindrical coprolites with fish scales and bones have been attributed to fishes (Fig. 13C; cf. Hunt \& Lucas 2012). Coprolite surfaces exhibit small
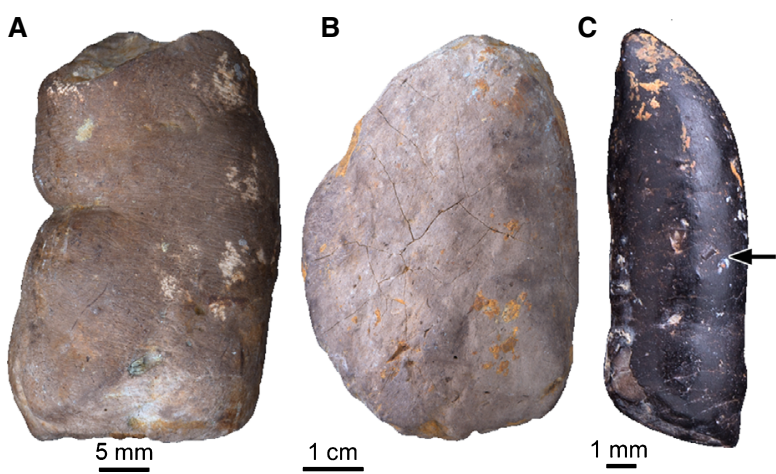

Fig. 13. Angeac-Charente coprolites. A, coprolite ANG Cop68 attributed to a crocodile producer. B, coprolite ANG Cop20 attributed to a vertebrate herbivorous producer. $\mathrm{C}$, coprolite ANG Cop73 attributed to fish producer. The arrow points at an inclusion of a fish lepidotrichium. Pictures: L. Cazes, MNHN. insect burrows and/or borings and one has traces similar to shark bite marks (Godfrey \& Smith 2010). These first results show a high diversity of shape $(>10$ morphotypes), variety of content (mostly fish remains for vertebrate producers) and producers (crocodiles and fishes) of Angeac-Charente coprolite assemblage, similar to that of the upper Barremian Las Hoyas site (Serran a de Cuenca, Spain) from the La Huérguina Formation (southwestern Iberian Basin), which was deposited in a lacustrine carbonate inland wetland ecosystem (Barrios-de Pedro et al. 2018).

It should also be noted that termite coprolites, assigned to the ichnotaxon Microcarpolithes hexagonalis Vangerow, 1954, have been found in the Unit 4 conglomerate from the 2010 field campaign (Fig. 2; CG1 2010) and are abundantly found in microremains. These micro-ichnofossils are often associated with Agathoxylon wood and several termite burrows have been observed in wood pieces. Termite coprolites are quite frequent in various lignite deposits of the mid-Cretaceous of Charentes (Colin et al. 2011; Néraudeau et al. 2012).

\section{Discussion}

\section{Depositional environment}

Néraudeau et al. (2012) proposed that the AngeacCharente bonebed was deposited in a freshwater depositional environment based on abundant freshwater taxa such as ostracods (Cypridea sp.), algae (Ovoidites parvus, Lecaniella sp.), unionoid bivalves and viviparid gastropods. However, they also proposed intermittent and brief connections to the sea based on a few (although possibly reworked) freshwater to brackish dinoflagellate cysts (Lobionella hirsute and Odontochitina imparilis), euryhaline ostracods (Fabanella boloniensis) in the upper part of the section (An 1, An2-3/Unit 4), and a few benthic foraminifers (Ammocycloloculina sp., Trocholina odukpaniensis) at different levels (An 1, An 3-4/Unit $2,3,4)$ and echinoid or bryozoan debris (Néraudeau et al. 2012; Polette et al. 2018). Benoît et al. (2017) supported this assumption and suggested that salinity of water varied at Angeac-Charente and that the marine influence increased higher in the stratigraphical section based on the presence and polymorphism of porocharaceans charophytes (An 1, An 2/Unit 4). They argued the depositional environment corresponded to the progradation of a deltaic-estuarine system rather than a peat mires or swamps based on the Angeac-Charente charophyte assemblage (abundance of porocharceans) and on the lignite and limestone facies (coal macerals and the vitrinite group, 
abundance of conifer remains and the absence of root traces at the base of the coal beds, indicating a parautochthonous accumulation of organic matter) that are similar to the Maastrichtian of the Vallcebre and Tremp Basins in Catalonia (Villalba-Breva et al. 2012; Villalba-Breva \& Martín-Closas 2013).

Our geochemical data contradict their conclusions. Following the diagenetic model of Reynard et al. (1999), the ratios of $(\mathrm{La} / \mathrm{Sm})_{\mathrm{N}},(\mathrm{La} / \mathrm{Yb})_{\mathrm{N}}$ and $(\mathrm{Sm} /$ $\mathrm{Yb})_{\mathrm{N}}$ clearly indicate that the sediment and fossil biogenic apatites accumulated under freshwater conditions (Fig. 5E, F). The Y/Ho ratios do not traduce a relative enrichment of Yttrium compared to REE neighbours (Fig. 5A) and are comparable to that of PAAS (Table S1). Large positive Yttrium anomalies (Y/Ho up to 150) normally develop when salinity increases along an estuarine profile due to mixing with seawater (Lawrence et al. 2006). Even a slight increase in salinity contributes to substantial increase in the Y/Ho ratios (Lawrence et al. 2006). This supports a freshwater depositional environment for the Angeac-Charente bonebed. Marine fossils are rare, poorly preserved and probably reworked, particularly the bryozoans, or may represent pollution from the Quaternary alluvium. Moreover, marine fossils were found only during the first field season and are rare in the tons of recently screened sediments. Significantly, we confidently reidentify the pliosauroid tibia (ANG 10-126) of Néraudeau et al. (2012) as the base of the neural arch of a sauropod vertebra.

The abundance of kaolinite in clay fraction of the bonebed (Néraudeau et al. 2012) as well as the abundance of verrucate spores with a strong affinity with the extant pantropical fern genus Lygodium (Polette et al. 2018) suggest subtropical to tropical conditions. Together, these observations indicate that the Angeac-Charente bonebed accumulated in a poorly oxygenated freshwater swamp/floodplain, dominated by cheirolepidiacean vegetation in a tropical to subtropical climate.

\section{A peculiar bonebed}

Eberth et al. (2007) analysed 315 localities and developed a bonebed classification scheme based on an array of characteristics. Bonebed that are simultaneously multitaxic ( $74 \%$ of the bonebeds), high diversity (58 \%), monodominant (29\%, Fig. 8) and mixed macrofossil/microfossil (13\%, Table S4), such as that of Angeac-Charente, are uncommon. Moreover, only $9 \%$ of bonebeds are simultaneously monotaxic/monodominant and mixed microfossil/macrofossil (Eberth et al. 2007). European Lower Cretaceous terrestrial bonebeds are also infrequent (only 6 out of 1084 after Eberth et al. 2007). They include Keymer
Tile Works site (Hauterivian) and the Cliff End Bone Bed (Valanginian) from the Wealden Group of UK, England (Cook 1995), the famous Bernissart locality (Berriasian-Barremian) from Belgium (Dollo 1882; Yans et al. 2012), Nehden site (Aptian) from Sauerland, Germany (Norman 1987), the Lens 204 from Cornet Bauxite Mine (Berriasian), Judetul Bihor, Romania (Benton et al. 1997), and the Las Hoyas site (upper Barremian) from Spain (Sanz et al. 2001).

The presence of both macrofossils and microfossils suggests a complex history of formation and development of the Angeac-Charente bonebed, resulting from multiple causes of death, concentration mechanisms, as well as bone accumulation and bone modification agents (Eberth et al. 2007). This is highlighted by the differential skeletal representation profile (Table S2), stages of preservation and modifications (breakage, abrasion and marks; Fig. 12) of the bones. The significant number of large-sized vertebrate taxa, the numerous evidences of predatory activity (Figs 12A$\mathrm{C}, 13)$, the probable gregarious habits of AngeacCharente ornithomimosaurs and stegosaurs, as well as the catastrophic mass death of the dominant species indicate that ecological and biologic concentrating mechanisms (e.g. gregariousness and predation) were likely the primary influences of Angeac-Charente bonebed formation. The predominance of low energy facies (clay) and the swampy environment of Angeac-Charente match the 'monodominant-wetland' bonebed pattern (Currie 2000; Eberth et al. 2007). The presence of facies of higher energy (Unit 2 at the base of the section of R3 and CG9, Unit 4 at the top of the section of the central area of the site and lenses in Unit 3; Fig. 3) sometimes rich in vertebrate microremains (R1 2014 lens in Unit 3 and Unit 2 at the base of R3), as well as the abundance of abraded sauropod bones, indicates the influence of hydraulic transport in concentrating bones. In addition, the high degree of bone breakage (Table S2, Fig. 7A, C, $\mathrm{E})$, the abundance of bone fragments with sharp edges (mostly turtles and ornithomimosaurs; Fig. 12A-C) and trample marks on bones (Fig. 12D), as well as the intense dinoturbation recorded in the sediments (Figs 9-11), demonstrates that the long-term in situ trampling of large animals was an important agent modifying the bone assemblage. Then, ecological and biologic processes seem to be the primary mechanisms of bone assemblage concentration, accumulation and modification (predation/scavenging, gregarious behaviour), but physical (hydraulic transport) and mixed physical/biologic processes (trampling) are also significant in some areas of the Angeac-Charente site.

None of the other European Lower Cretaceous terrestrial bonebeds shows similar pattern and 
environment. Only the macrofossil Nehden bonebed, representing a small lacustrine sinkhole wetland environment, shares similarities with Angeac-Charente, namely, a mixture of bone concentration processes, evidence of group behaviour, a mass death occurrence (Iguanodon) and limited time averaging (Norman 1987). The unusual characteristics of the Angeac-Charente bonebed is function of its swampy environment, a rare environment in the bonebed record. Only two swamp-related bonebeds were recognized by Eberth et al. (2007): the high diversity, multidominant and macrofossil Pyramid Valley (late Holocene, Holdaway \& Worthy 1997) and Glencrieff (early Holocene, Worthy \& Holdaway 1996) bonebeds, both near the Waikari locality in New Zealand. These two bone assemblages formed in peat swamp deposits and are mainly composed of disarticulated skeletons of birds, reptiles and small mammals. They likely resulted from long term/cyclic miring or vagrant death of individuals and predation/scavenging activity (Worthy \& Holdaway 1996; Holdaway \& Worthy 1997). Thus, further study of the taphonomy of Angeac-Charente bonebed will provide new insights about terrestrial ecosystems of the Lower Cretaceous of Europe, as well as mechanisms of formation and development of bonebeds in a swamp environment.

\section{Fossil-Lagerstätte}

The Angeac-Charente site is a rich locality with an unusual abundance, diversity, quality and preservation of fossils concentrated in a small area and within a single chronostratigraphical unit. A fossil-Lagerstätte is defined as a cbody of rock that contains an unusual amount of palaeontological information, in terms of quality and quantity' (Seilacher 1970). Following this definition, Angeac-Charente site qualifies as fossil-Lagerstätte.

Abundance is demonstrated by the high number and density of each kind of fossil. Notably, the bonebed of Angeac-Charente is first and foremost a plant-debris bed, often in dense accumulations (Fig. 6A-C), making it difficult to conduct a quantitative analysis. Moreover, mollusc moulds preserved in clay (Néraudeau et al. 2012), tracks (dinoturbation in the central area of the site, Fig. 9) and marks on bone cortical surfaces (Fig. 12) are also exceedingly abundant and impractical to count. Vertebrate body fossils and coprolites are also present in high densities (Table S5). Therefore, containing an 'accumulation of disarticulated hard parts of organisms' (Seilacher 1970) and a visible abundance of trace fossils (e.g. Hunt et al. 2005), Angeac-Charente site can be unequivocally qualified as both Body fossil and Ichnofossil
Concentration-Lagerstätte (Mangano \& Buatois 1995; Hunt et al. 2005; Savrda 2007).

Angeac-Charente fossils show an impressive taxonomic diversity, with at least 100 taxa as well as a wide range of fossil kinds such as bones, wood, coprolites and tracks, usually not found in a same chronostratigraphical unit. Vertebrate body fossils (both macro- and microremains) represent at least 38 taxa. Plant remains are represented by at least 37 species of palynomorphs, including coniferous wood (Agathoxylon trunk and branches; Fig. 6), cuticles, isolated leaves and leafy twigs (Cheirolepidiaceae Watsoniocladus), cones and scales; seeds; circinate pinnae and spores of ferns and charophyte algae taxa represented by gyrogonites (Néraudeau et al. 2012; Benoît et al. 2017; Polette et al. 2018). At least 11 invertebrate taxa are present, including unionoid bivalves, viviparid gastropods and ostracod crustaceans (Néraudeau et al. 2012). Ichnofossils comprise ten coprolite morphotypes produced by several vertebrate and invertebrate taxa, tracks produced by at least two vertebrate taxa, and vertebrate and invertebrate marks on bones and coprolites. To our knowledge, no other bonebed has yielded such a diversity of taxa and fossil kinds. In addition, each type of fossil is exquisitely preserved. Bone, tooth, plant, mollusc mould, coprolite and track fossils conserve their original, three-dimensional shape (Figs 6, $7,9-13)$. Several track casts have preserved the anatomy of pes and manus, the mould of skin impressions (slides marks and grooves) and/or the " $4^{\text {th }}$ dimension' depicting the pes or manus movement in the soil (Figs 9A, C). Bone surface modifications are easily discerned, including fine and shallow trample marks and internal striae in crocodile tooth marks (Fig. 12; Gônet et al. 2018). Coprolites contain plant and vertebrate remains as well as surficial insect marks (Fig. 13). The original definition of (Body fossil) Conservation-Lagerstätte is the preservation of organic skeletal substances (for example, chitin) and articulated skeletons (arthropods, echinoderms, vertebrates) (Seilacher, 1970). Although Angeac-Charente does not match that definition, the exceptional quality of many hard parts of body fossils of AngeacCharente is noteworthy. Notably, concerning the preservation of organic material, preliminary biogeochemic investigation found carbon in the haversian canals of an ornithomimosaur bone that could correspond to that of the original organic tissue (e.g. blood vessels; Pascale Gautret, personal communication). The exquisite quality of preservation of most of the ichnofossils qualifies the Angeac-Charente site as an Ichnofossil Conservation-Lagerstätte (Mangano \& Buatois 1995; Savrda 2007), and by extension, as a Fossil Conservation-Lagerstätte. 


\section{Snapshot}

As stated above, both previous clay diffraction analysis (Néraudeau et al. 2012) and REY analyses indicate that the sediments and fossils experienced a coeval deposition, rapid burial and early diagenesis in poorly oxygenated freshwater conditions and minimal time averaging. Moreover, the AngeacCharente site has preserved exceptional 'frozen' sedimentological and taphonomic processes in action such as rebalance loads (Fig. 4), convolute lamination (Figs 3, 4A, 10B, 11A), '4-D' track casts (Figs 9A, C), as well as a spectacular cases of bone and sediment modifications due to trampling (Figs 9C, 10). In addition, the richness and diversity of biologic activity traces (coprolites, biologic marks on bones, tracks in sediments) and biogenic productions (isolated crocodile and dinosaur teeth) indicate that the swamp depositional environment of Angeac-Charente was the life habitat of most of the recovered vertebrates. Thus, the bonebed was established in a limited time and space and reflects a real 'snapshot' of an Early Cretaceous European freshwater ecosystem.

\section{Conclusion}

The Angeac-Charente locality is a fossil-Lagerstätte that contains extraordinary palaeontological (body fossil), palaeoenvironmental, palaeobiological, palaeoecological and palaeobehavioural (ichnofossil) information. Its peculiar taphonomy, rapid deposition and preservation of both faunal and floral components present a 'snapshot' of an early Cretaceous wetland swamp ecosystem - an environment that rarely preserves bonebeds. Tooth marks on the bones and coprolite contents show evidence of crocodyliform predation and/or scavenging on turtles, ornithomimosaurs and fishes. Abundance and distribution of ornithomimosaurs remains and of stegosaur tracks suggest gregarious behaviour for these two taxa, and a mass mortality event for the ornithomimosaurs. The abundance of tracks and trampling marks on bones indicates intense dinoturbation of the site. Further studies on various aspects of the locality (e.g. palaeontology, sedimentology, taphonomy, ichnology and geochemistry) will allow to test several hypotheses proposed here and reconstruct the structure of the living community within its environment, including inter- and intraspecific interactions as, for example, predatorprey relations, food webs, conspecific relationships (herding, population structures), as well as behaviour (predation, sociality). The Angeac-Charente
Lagerstätte really opens up a 'window' into terrestrial ecosystems across the Late Jurassic to Early Cretaceous transition in Europe and provides new insights about bonebeds formation in peculiar swamp environments.

Acknowledgements. - The Angeac-Charente project would not have been possible without the agreement and collaboration of the Audoin Company, especially the technical work done by the quarry workers. We are deeply grateful to Jean-Marie Audoin, head of the company, who passed away on 9 May 2018, and wish to honour his memory. We thank the Nouvelle Aquitaine Region for funding part of Lee Rozada's doctoral thesis and La Charente department, the Grand Cognac urban community and AngeacCharente for financing the excavation since 2011. We also thank the Fundación Conjunto Palaeontológico de Teruel-Dinópolis, Departamento de Innovación, Investigación and Universidad (Gobierno de Aragón) and FEDER Aragón 2014-2020 ('Construyendo Europa desde Aragón') financing the Research Group E04_17R FOCONTUR and the Spanish Ministerio de Ciencia, Innovación y Universidades (PGC2018-094034-B-C22) for financing the Angeac-Charente fieldwork missions of Rafael RoyoTorres. We acknowledge the team of the Musée d'Angoulême for their availability and help during collection studies. We especially thank Jean-François Tournepiche, Chief Conservator of Cultural Heritage attached to the Musée of Angoulême, for organizing fieldwork and scientific outreach. From the Muséum National d'Histoire Naturelle, Paris, we thank Lilian Cazes for photographs and Yohan Despres, Hélène Bourget and Renaud Vacant for technical work fossil preparation. We also thank Loïc Bocat and Patrick Blanchier for the pictures and Dominique Abit for drone pictures. We thank Renaud Bourget for preparation work and fossil identification help, and Jordan Gônet for turtle taphonomic insights. We thank Pascale Gautret from the Institut des Sciences de la Terre d'Orléans (ISTO-CNRS) for her preliminary biogeochemical investigations. Finally, we acknowledge the contribution of the professional and amateur palaeontologists as well as the numerous students who participated in excavations since 2010, counting thousands of bone fragments and our rich scientific discussions.

\section{References}

Allain, R., Vullo, R., Leprince, A., Néraudeau, D. \& Tournepiche, J.F. 2011: An ornithomimosaur-dominated bonebed from the Early Cretaceous of southwestern France. Journal of Vertebrate Palaeontology 31 (Supplement), 61.

Allain, R., Rozada, L. \& Vullo, R. 2013: A cross-perspective into the Early Cretaceous dinosaur faunas from Europe and Asia: new data on the dinosaurs from the Savannakhet Bassin (Laos) and from the lignitic bonebed of Angeac-Charente (France). In VI Jornadas Internacionales sobre Paleontología de Dinosaurios y su Entorno, Salas de los Infantes, Spain.

Allain, R., Vullo, R., Le Loeuff, J. \& Tournepiche, J.-F. 2014: European ornithomimosaurs (Dinosauria, Theropoda): an undetected record. Geologica Acta 12, 127-135.

Allen, J.R.L. 1982: Sedimentary structures and physical basis. In Developments in Sedimentology, vol. 30, Part. B, Volume II, 662 pp. Elsevier Science, Amsterdam.

Andrews, P. \& Cook, J. 1985: Natural modifications to bones in a temperate setting. Man 20, 675-691.

Baghai-Riding, N.L. \& DiBenedetto, J.N. 2001: An unusual dinosaur coprolite from the Campanian Aguha Formation, Texas. Gulf Coast Association of Geological Societies Transactions 51, 10-20.

Barrios-de Pedro, S., Poyato-Ariza, F.J., Moratalla, J.J. \& Buscalioni, D. 2018: Exceptional coprolite association from the Early Cretaceous continental Lagerstatte of Las Hoyas, Cuenca, Spain. PLoS One 13, e0196982. 
Batten, D.J. 2002: Palaeoenvironmental setting of the Purbeck Limestone Group of Dorset, Southern England. The Palaeontological Association, Special Papers in Palaeontology 68, 13-20.

Bau, M. \& Dulski, P. 1999: Comparing yttrium and rare earths in hydrothermal fluids from the Mid-Atlantic Ridge: implications for $\mathrm{Y}$ and REE behaviour during near-vent mixing and for the Y/Ho ratio of Proterozoic seawater. Chemical Geology 155, 7790.

Behrensmeyer, A.K. 2007: Chapter 2: Bonebeds through Time. In Rogers, R.R., Eberth, D.A. \& Fiorillo, A.R. (eds): Bonebeds: Genesis, Analysis, and Paleobiological Significance, 65-97. University of Chicago Press, Chicago.

Behrensmeyer, A.K., Gordon, K.D. \& Yanagi, G.T. 1986: Trampling as a cause of bone surface damage and pseudocutmarks. Nature 319, 768-771.

Benoît, R.-A., Néraudeau, B. \& Martín-Closas, C. 2017: A review of the Late Jurassic-Early Cretaceous charophytes from the northern Aquitaine Basin in south-west France. Cretaceous Research 79, 199-213.

Benton, M.J., Cook, E., Grigorescu, D., Popa, E. \& Tallódi, E. 1997: Dinosaurs and other tetrapods in an Early Cretaceous bauxite-filled fissure, northwestern Romania. Palaeogeography, Palaeoclimatology, Palaeoecology 130, 275-292.

Bertin, T.J.C., Thivichon-Prince, B., LeBlanc, A.R.H., Caldwell, M.W. \& Viriot, L. 2018: Current Perspectives on tooth implantation, attachment, and replacement in Amniota. Frontiers in Physiology 9, 1630.

Binford, L.R. 1981: Bones: Ancient Men and Modern Myths, 319 p. Academic Press, New York.

Braun, J.-J., Pagel, M., Herbilln, A. \& Rosin, C. 1993: Mobilization and redistribution of REEs and thorium in a syenitic lateritic profile: a mass balance study. Geochimica et Cosmochimica Acta 57, 4419-4434.

Braun, J.-J., Viers, J., Dupré, B., Polve, M., Ndam, J. \& Muller, J.P. 1998: Solid/liquid REE fractionation in the lateritic system of Goyoum, East Cameroon: the implication for the present dynamics of the soil covers of the humid tropical regions. Geochimica et Cosmochimica Acta 62, 273-299.

Brinkman, D.B., Eberth, D.A. \& Currie, P.J. 2007: From Bonebeds to Palaeobiology: applications of bonebed data. In Rogers, R.R., Eberth, D.A. \& Fiorillo, A.R. (eds): Bonebeds: Genesis, Analysis, and Paleobiological Significance, 221-263. University of Chicago Press, Chicago.

Burton, A.C. 1998: A Taphonomic Study of the Wealden Beds of Southern Britain. Unpublished PhD thesis, University of Cambridge, Cambridge, $197 \mathrm{pp}$.

Buscalioni, A.D. \& Fregenal-Martınez, M.A. 2010: A holistic approach to the palaeoecology of Las Hoyas Konservat-Lagerstätte. Mesozoic Terrestrial Ecosystems and Biotas, Journal of Iberian Geology 2, 297-326.

Campos-Soto, S., Cobos, A., Caus, E., Benito, E.I., Fernández-Labrador, L., Suarez-Gonzalez, P., Quijada, I.E., Mas, R., RoyoTorres, R. \& Alcalá, L. 2017: Jurassic Coastal Park: A great diversity of palaeoenvironments for the dinosaurs of the Villar del Arzobispo Formation (Teruel, eastern Spain). Palaeogeography, Palaeoclimatology, Palaeoecology 485, 154-177.

Chin, K. 2007: The palaeobiological implications of herbivorous dinosaur coprolites from the Upper Cretaceous Two Medicine Formation of Montana: why eat wood? Palaios 22, 554-566.

Chure, D.J., Fiorillo, A.R. \& Jacobsen, A. 1998: Prey bone utilization by predatory dinosaurs in the Late Jurassic of North America, with comments on prey bone use by dinosaurs throughout the Mesozoic. Gaia 15, 227-232.

Cobos, A., Royo-Torres, R., Luque, L., Alcalá, L. \& Mampel, L. 2010: An Iberian stegosaurs paradise: The Villar del Arzobispo Formation (Tithonian-Berriasian) in Teruel (Spain). Palaeogeography, Palaeoclimatology, Palaeoecology 293, 223-236.

Cobos, A., Gascó, F., Royo-Torres, R., Lockley, M.G. \& Alcalá, L. 2016: Dinosaur Tracks as 'Four-Dimensional Phenomena' reveal how different species moved. In Falkingham, P.L., Marty, D. \& Richter, A. (eds): Dinosaur Tracks - The Next Steps, 245-255. Indiana University Press, Indiana.
Colin, J.P., Néraudeau, D., Nel, A. \& Perrichot, V. 2011: Termite coprolites (Insecta: Isoptera) from the Cretaceous of western France: a palaeoecological insight. Revue de Micropaléontologie 54, 129-139.

Cook, E. 1995: Taphonomy of two non-marine Lower Cretaceous bone accumulations from southeastern England. Palaeogeography, Palaeoclimatology, Palaeoecology 116, 263-270.

Cullen, T.M., Ryan, M.J., Schröder-Adams, C., Currie, P.J. \& Kobayashi, Y. 2013: An ornithomimid (Dinosauria) bonebed from the Late Cretaceous of Alberta, with implications for the behaviour, classification, and stratigraphy of North American ornithomimids. PLoS One 8, e58853.

Currie, P.J. 2000: Possible evidence of gregarious behaviour in tyrannosaurids. Gaia 15, 123-133.

Diffley, R.L. \& Ekdale, A.A. 2002: Footprints of Utah's last dinosaurs; tracks beds in the Upper Cretaceous (Maastrichtian) North Horn Formation of the Wasatch Plateau, central Utah. Palaios 17, 327-346.

Dollo, L. 1882: Première note sur les dinosauriens de Bernissart. Bulletin du Musée Royal d'Histoire Naturelle de Belgique 1, 5580.

Eberth, D.A., Shannon, M. \& Noland, B.G. 2007: A bonebeds database: classification, biases, and patterns of occurrence. In Rogers, R.R., Eberth, D.A. \& Fiorillo, A.R. (eds): Bonebeds: Genesis, Analysis, and Paleobiological Significance, 103-131. University of Chicago Press, Chicago.

Edmund, A.G. 1962: Sequence and rate of tooth replacement in the Crocodilia. Life Sciences Division of the Royal Ontario Museum of Zoology, Palaeontology Contribution 56, 1-90.

Erickson, G.M. 1996a: Daily deposition of dentine in juvenile alligator and assessment of tooth replacement rates using incremental line counts. Journal of Morphology 228, 189-194.

Erickson, G.M. 1996b: Incremental lines of von Ebner in dinosaurs and the assessment of tooth replacement rates using growth line counts. Proceedings of the National Academy of Sciences of the United States of America 93, 14623-14627.

Esri 1999-2015: ArcGIS Desktop: Release 10.3.1. [software]. Environmental Systems Research Institute, Inc. (Esri), Redlands.

Esri 2012: ArcGIS 10.1 Projection Engine Tables: Geographic and Vertical Coordinate Systems, Datums and Vertical Datums, Spheroids, Prime Meridians, and Angular Units of Measure. Environmental Systems Research Institute, Inc. (Esri), Redlands, CA. http://desktop.arcgis.com/fr/arcmap/10.3/guidebooks/map-projections/about-geographic-coordinate-systems. htm

Fernandez-Jalvo, Y. \& Andrews, P. 2016: Atlas of Taphonomic Identifications: Images of Fossil and Recent Mammal Bone Modification, 359 pp. Springer, Berlin.

Fiorillo, A.R. 1991: Prey bone utilization by predatory dinosaurs. Palaeogeography, Palaeoclimatology, Palaeoecology 88, 157166.

Fuchs, T. 1895: Studien über Fucoiden und Hieroglyphen. Kaiserlichen Akademie der Wissenschaften / Mathematisch-Naturwissenschaftliche Classe 62, 369-448.

Gatesy, S.M. 2001: Skin impressions of Triassic theropods as records of foot movement. Bulletin of the Museum of Comparative Zoology 156, 137-149.

Ghosh, P., Bhattacharya, S.K., Sahni, A., Kar, R.K., Mohabey, D.M. \& Ambwani, K. 2003: Dinosaur coprolites from the Late Cretaceous (Maastrichtian) Lameta Formation of India: Isotopic and other markers suggesting a $\mathrm{C}_{3}$ plant diet. Cretaceous Research 24, 743-750.

Godfrey, S.J. \& Smith, J.B. 2010: Shark-bitten vertebrate coprolites from the Miocene of Maryland. Naturwissenschaften 97, 461-7.

Gônet, J., Rozada, L., Bourgeais, R. \& Allain, R. 2018: Taphonomic study of a pleurosternid turtle shell from the Early Cretaceous of Angeac-Charente, southwest France. Lethaia 52, 232-243.

Hartig, T. 1848: Beitrage zur Geschichte der Pflanzen und zur Kenntnis der norddeutschen Braunkohlen-Flora. Botanische Zeitung 6, 185-190.

Hasiotis, S.T., Platt, B.F., Hembree, D.I. \& Everhart, M. 2007: The trace-fossil record of vertebrates. In Miller, W. (ed): Trace 
Fossils: Concepts, Problems, Prospects, 196-218. Elsevier, Amsterdam.

Hassler, A., Martin, J.E., Amiot, R., Tacail, T., Godet, A.F., Allain, R. \& Balter, V. 2018: Calcium isotopes offer clues on resource partitioning among Cretaceous predatory dinosaurs. Proceedings of the Royal Society B: Biological Sciences 285, 1876.

Holdaway, R.N. \& Worthy, T.H. 1997: A reappraisal of the late Quaternary fossil vertebrates of Pyramid Valley Swamp, North Canterbury, New Zealand. New Zealand Journal of Zoology 24, 69-121.

Hunt, A.P. \& Lucas, S.G. 2012: Descriptive terminology of coprolites and recent feces. New Mexico Museum of Natural History and Science Bulletin 57, 153-160.

Hunt, A.P., Chin, K. \& Lockley, M.G. 1994: The palaeobiology of vertebrate coprolites. In Donovan, S.K. (ed): The Palaeobiology of Trace Fossils, 221-240. John Wiley \& Sons, Chichester.

Hunt, A.P., Lucas, S.G. \& Pyenson, N.D. 2005: The significance of the Union Chapel Mine site: a Lower Pennsylvanian (Westphalian A) ichnological Konzentrat-Lagerstätte, Alabama, USA. Alabama Paleontological Society Monograph $1,3-14$.

Jennings, D.S. \& Hasiotis, S.T. 2006: Taphonomic analysis of a dinosaur feeding site using geographic information systems (GIS), Morrison Formation, Southern Bighorn Basin, Wyoming, USA. Palaios 21, 480-492.

Kuenen, P.H. 1953: Significant features of graded bedding. American Association of Petroleum Geologists Bulletin 37, 1044.

Lawrence, M.G., Greig, A., Collerson, K.D. \& Kamber, B.S. 2006: Rare earth element and yttrium variability in South East Queensland waterways. Aquatic Geochemistry 12, 39-72.

Lockley, M.G. 1986: The paleobiological and paleoenvironmental importance of dinosaur footprints. Palaios 1, 37-47.

Lockley, M.G. 1994: Dinosaur ontogeny and population structure: Interpretations and speculations based on fossil footprints. InCarpenter, K., Hirsch, K.F., Horner, J.R. (eds): Dinosaur Eggs and Babies, 347-365. Cambridge University Press, Cambridge.

Lockley, M.G. 1998: The vertebrate track record. Nature 396, 429-432.

Lubkin, S.R. 1997: On pattern formation in reptalia dentition. Journal of Theoretical Biology 186, 145-157.

Macar, P. 1948: Les pseudonodules du Famémien et leur origine. Annales de la Société Géologique de Belgique 72, 47-74.

Mangano, M.G. \& Buatois, L.A. 1995: A conceptual framework of trace fossil-Lagerstätten. In II International Symposium on Lithographic Limestones, Lleida, Cuenca, Spain, Extended Abstract, Ediciones de la Universidad Autónoma de Madrid, 103-105.

Milán, J. 2012: Crocodylian scatology. A look into morphology, internal architecture, inter-and intraspecific variation and prey remains in extant crocodylian feces. New Mexico Museum of Natural History and Science Bulletin 57, 65-72.

Milán, J., Kofoed, J. \& Bromley, R.G. 2010: Crocodylian-chelonia carnivory: bite traces of dwarf caiman, Palaeosuchus palpebrosus, in red-eared slider, Trachemys scripta, carapaces. New Mexico Museum of Natural History and Science Bulletin 51, 171-174.

Néraudeau, D., Allain, R., Ballèvre, M. et al. 2012: The Hauterivian-Barremian lignitic bone bed of Angeac-Charente (Charente, south-west France): stratigraphical, palaeobiological and palaeogeographical implications. Cretaceous Research 37, $1-14$.

Niedźwiedzki, G., Gorzelak, P. \& Sulej, T. 2011: Bite traces on dicynodont bones and the early evolution of large terrestrial predators. Lethaia $44,87-92$.

Njau, J.K. \& Blumenschine, R.J. 2006: A diagnosis of crocodile feeding traces on larger mammal bone, with fossil examples from the Plio-Pleistocene Olduvai Basin, Tanzania. Journal of Human Evolution 50, 142-162.

Njau, J.K. \& Gilbert, H. 2016: Standardizing terms for crocodile induced bite marks on bone surfaces in light of the frequent bone modification equifinality found to result from crocodile feeding behaviour, stone tool modification, and trampling. Forost Occasional Publications No. 3.
Norman, D.B. 1987: A mass-accumulation of vertebrates from the Lower Cretaceous of Nehden (Sauerland), West Germany. Proceedings of the Royal Society of London 230, 215-255.

Noto, C.R., Main, D.J. \& Drumheller, S.K. 2012: Feeding traces and paleobiology of a Cretaceous (Cenomanian) crocodyliform: example from the Woodbine Formation of Texas. Palaios $27,105-115$.

Olsen, S.L. \& Shipman, P. 1988: Surface modification on bone: Trampling versus butchery. Journal of Archaeological Science 15, 535-553.

Owen, R. 1842: Report on British Fossil Reptiles, part II. Report of the British Association for the Advancement of Science 11, 60204.

Polette, F., Batten, D.J. \& Néraudeau, D. 2018: Re-examination of the palynological content of the Lower Cretaceous deposits of Angeac, Charente, south-west France: Age, palaeoenvironment and taxonomic determinations. Cretaceous Research 90, 204221.

Poole, D.G. 1961: Notes on tooth replacement in the Nile crocodile. Proceedings of the Zoological Society of London 136, 131140.

Potter, P.E. \& Pettijohn, F.J. 1963: Paleocurrents and Basin Analysis, 296. Springer, Berlin.

Prasad, V., Strömberg, C.A.E., Alimohammadian, H. \& Sahni, A. 2005: Dinosaur coprolites and the early evolution of grasses and grazers. Science 310, 1177-1180.

Qvarnström, M., Niedźwiedzki, G. \& Ahlberg, P.E. 2019a: Tyrannosaurid-like osteophagy by a Triassic archosaur. Scientific Reports 9, 925.

Qvarnström, M., Vikberg Wernström, J., Piechowski, R., Tałanda, M., Ahlberg, P.E. \& Niedźwiedzki, G. 2019b: Beetle-bearing coprolites possibly reveal the diet of a Late Triassic dinosauriform. Royal Society Open Science 6, 181042.

Reisz, R.R. \& Tsuji, L.A. 2006: An articulated skeleton of Varanops with bite marks: the oldest known evidence of scavenging among terrestrial vertebrates. Journal of Vertebrate Palaeontology 26, 1021-1023.

Reynard, B., Lécuyer, C. \& Grandjean, P. 1999: Crystal-chemical controls on rare-earth element concentrations in fossil biogenic apatites and implications for paleoenvironmental reconstructions. Chemical Geology 155, 233-241.

Richter, G. \& Baszio, S. 2001: Traces of a limnic food web in the Eocene Lake Messel: a preliminary report based on fish coprolite analyses. Palaeogeography, Palaeoclimatology, Palaeoecology 166, 345-368.

Rogers, R.R. \& Kidwell, S.M. 2007: A conceptual framework for the genesis and analysis of vertebrate skeletal concentrations. In Rogers, R.R., Eberth, D.A. \& Fiorillo, A.R. (eds): Bonebeds: Genesis, Analysis, and Paleobiological Significance, 7-63. University of Chicago Press, Chicago.

Rogers, R.R., Krause, D.W. \& Rogers, K.C. 2003: Cannibalism in the Madagascan dinosaur Majungatholus atopus. Nature 422, $515-518$.

Rousseau, T.C.C., Sonke, J.E., Chmeleff, J., van Beek, P., Souhaut, M., Boaventura, G., Seyler, P. \& Jeandel, C. 2015: Rapid neodymium release to marine waters from lithogenic sediments in the Amazon estuary. Nature Communications 6, 7592.

Royo-Torres, R. \& Upchurch, P. 2012: The cranial anatomy of the sauropod Turiasaurus riodevensis and implications for its phylogenetic relationships. Journal of Systematic Palaeontology 10, 553-583.

Royo-Torres, R., Cobos, A. \& Alacalá, L. 2006: A giant European dinosaur and a new sauropod clade. Science 314, 1925-1927.

Royo-Torres, R., González, A., Mampel, L., Gascó, F., Ayala, D., Cobos, A., Espílez, E., Verdú, J. \& Alcalá, L. 2013: Unusual dinosaur tracksite on Albian (Escucha Formation) soft sediments in Oliete (Teruel, Spain). In VI Jornadas Internacionales sobre Paleontología de Dinosaurios y su Entorno. Salas de los Infantes, Burgos.

Rozada, L. 2014: An ornithomimosaur (Dinosauria) herd from the Lower Cretaceous of Angeac-Charente (Charente, France). 1st Young Natural History scientists Meeting, Program and Abstracts, 2014: 11. 
Rozada, L.2017: Inferring ecology and behaviour of extinct vertebrates: the example of the dinosaur palaeontological site of Angeac-Charente (Lower Cretaceous, Charentes, France). 13th Ecology and Behaviour Meeting, 2017.

Rozada, L., Allain, R., Vullo, R., Leprince, A. \& Tournepiche, J.F. 2014: Taphonomy of the ornithomimosaur dinosaur herd from the Early Cretaceous lignitic bone bed of Angeac-Charente (France). Journal of Vertebrate Paleontology, Program and Abstracts 2014, 217-218.

Rozada, L., Allain, R. \& Tournepiche, J.-F. 2016: A trampling experiment and its application to an open-air swampy environment and non-anthropic context. 4th International Council for Archaeozoology Taphonomy Working Group. MNHN, Paris.

Rozada, L., Allain, R. \& Tournepiche, J.F. 2018: Trampling experiments on bones in fine soft and sediments. Quaternaire 29, 3944.

Ryan, M.J., Russell, A.P., Eberth, D.A. \& Currie, P.J. 2001: The taphonomy of a Centrosaurus (Ornithischia: Ceratopsidae) bone beds from the Dinosaur Park Formation (Upper Campanian), Alberta, Canada, with comments on cranial ontogeny. Palaios 16, 482-506.

Sanz, J.L., Wenz, S., Yebenes, A., Estes, R., Martinez-Delclos, X., Jimenez-Fuentes, E., Diéguez, C., Buscalioni, A.D., Barbadillo, L.J. \& Via, L. 1988: An Early Cretaceous faunal and floral continental assemblage: Las Hoyas fossil site (Cuenca, Spain). Geobios 21, 611-635.

Sanz, J.L., Chiappe, L.M., Fernández-Jalvo, Y., Sánchez-Chillón, B., Poyato-Ariza, F.J. \& Pérez-Moreno, B.P. 2001: An Early Cretaceous pellet. Nature 409, 998-999.

Savrda, C.E. 2007: Taphonomy of trace fossils. In Miller, W. (ed): Trace Fossils: Concepts, Problems, Prospects, 92-109. Geology Department Humboldt, State University, Arcata.

Seilacher, A. 1970: Begriff und Bedeutung der Fossil-Lagerstätten (Concept and meaning of fossil lagerstätten). Neues Jahrbuch für Geologie und Paläontologie, Monatshefte, 34-39.

Tanke, D.H. \& Currie, P.J. 1998: Head-biting behaviour in theropod dinosaurs: palaeopathological evidences. Gaia 15, 167-184.

Trotter, J.A., Barnes, C.R. \& McCracken, A.D. 2016: Rare earth elements in conodont apatite: Seawater or pore-water signatures? Palaeogeography, Palaeoclimatology, Palaeoecology 462, 92-100.

Trueman, C.N. 1999: Rare earth element geochemistry and taphonomy of terrestrial vertebrate assemblages. Palaios 14, $555-568$.

Trueman, C.N. \& Benton, M.J. 1997: A geochemical method to trace the taphonomic history of reworked bones in sedimentary settings. Geology 25, 263.

Vangerow, E.F. 1954: Megasporen un andere Pflanzliche Mikrofossilien aus der Aachener Kreide. Palaeontographica, Abteilung B 96, 24-38.

Varricchio, D.J., Sereno, P.C., Zhao, X., Tan, L., Wilson, J.A. \& Lyon, G.H. 2008: Mud-trapped herd captures evidence of distinctive dinosaur sociality. Acta Palaeontologica Polonica 53, $567-578$.
Villalba-Breva, S. \& Martín-Closas, C. 2013: Upper Cretaceous paleogeography of the Central Southern Pyrenean Basins (Catalonia, Spain) from microfacies analysis and charophyte biostratigraphy. Facies 59, 319-345.

Villalba-Breva, S., Martín-Closas, C., Marmi, J., Gomez, B. \& Fernandez-Marron, M.T. 2012: Peat-forming plants in the Maastrichtian coals of the Eastern Pyrenees. Geologica Acta 10, 189207.

Whyte, M.A. \& Romano, M. 1994: Probable sauropod footprints from the Middle Jurassic of Yorkshire England. Gaia 10, 1526.

Worthy, T.H. \& Holdaway, R.N. 1996: Quaternary fossil faunas, overlapping taphonomies, and palaeofaunal reconstruction in North Canterbury, South Island, New Zealand. Journal of the Royal Society of New Zealand 26, 275-361.

Yans, J., Dejax, J. \& Schnyder, J. 2012: On the age of the Bernissart Iguanodons. In Godefroit, P. (ed): Bernissart Dinosaurs and Early Cretaceous Terrestrial Ecosystems, 79-86. Indiana University Press, Indiana.

\section{Supporting Information}

Additional supporting information may be found online in the Supporting Information section at the end of the article.

Table S1. Rare earth elements and Yttrium (REY) concentration (ppm) of post-Archean Australian Shale (PAAS), sediment samples from the stratigraphical section S.CG3 2015 and biogenic apatite and enclosing sediment samples from the bonebed of Angeac-Charente.

Table S2. Number of identified specimens (NISP) and number of unidentified specimens (NUSP) of vertebrate bones and teeth.

Table S3. Comparison of the name of the units used by previous authors and this study.

Table S4. Numbers of macrofossils and microfossils.

Table S5. Number (N), proportion (\%) and density $\left(\mathrm{D}, \mathrm{N} / \mathrm{m}^{2}\right)$ of identified (NISP) and unidentified (NUSP) vertebrate macroremains (bodyfossils and coprolites) depending on taxon and plot. 